\title{
Eocene dinoflagellate cysts from the Sołokija Graben (Roztocze, SE Poland): biostratigraphy and palaeoenvironment
}

\author{
Przemysław GEDL ${ }^{1, *}$ \\ 1 Institute of Geological Sciences, Polish Academy of Sciences, Senacka 1, 31-002 Kraków, Poland
}

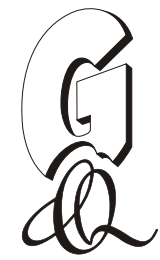

Gedl, P., 2014. Eocene dinoflagellate cysts from the Sołokija Graben (Roztocze, SE Poland): biostratigraphy and palaeoenvironment. Geological Quarterly, 58 (4): 707-728, doi: 10.7306/gq.1167

\begin{abstract}
The Sołokija Graben is a tectonic structure in Roztocze, in southeastern Poland, unique by its infill of Eocene marine strata. The more than $40 \mathrm{~m}$ thick sandy succession is the only well-dated palaeontological evidence of the Eocene marine transgression of an epicontinental sea in this part of Poland: the surrounding area is devoid of coeval marine strata, which were since eroded away. The Sołokija Graben succession is hence crucial for the palaeogeographic reconstruction of southeastern Poland during the Eocene as well as for the tectonic history of this region. To obtain precise age determination, the $33 \mathrm{~m}$ thick succession of loamy sands that fill the Sołokija Graben at Leliszka and the $4 \mathrm{~m}$ thick succession at Łaszczówka were sampled via borehole cores for dinoflagellate cysts. Samples from Łaszczówka are barren, whereas those from Leliszka contain rich and taxonomically diverse assemblages. Their biostratigraphical interpretation supports previous results suggesting a Bartonian age for most of the Sołokija Graben succession; the postulated Priabonian age of its non-calcareous part was documented in its uppermost part only. The palynological record also allows reconstruction of the sedimentary setting of the Leliszka succession. The basal part of the Bartonian was deposited in a shallow but extensive marine basin characterized by normal salinity and relatively high-energy hydrodynamic conditions. Subsequently, marine basin underwent gradual shallowing with a temporary halt in sedimentation. During the Late Bartonian the basin became brackish. A short-duration Early Priabonian marine basin was characterized by shallow-marine conditions; it became brackish during its final stage. Comparison with neighbouring Eocene deposits of the epicontinental and Carpathian basins shows that the marine basin at Roztocze was presumably connected with both during the Bartonian, and separated from the Carpathian basin during the Early Priabonian. Factors controlling the seaway pattern of the Roztocze Basin included eustasy and tectonic movements, the former dominating during the Bartonian, and co-occurring with uplift of the Meta-Carpathian Swell during the Early Priabonian.
\end{abstract}

Key words: dinoflagellate cysts, biostratigraphy, Eocene, epicontinental basin, Roztocze, SE Poland.

\section{INTRODUCTION}

The Middle-Upper Eocene deposits of the epicontinental sea are widespread in the northern part of Poland whereas they are absent from the southern parts of the country (the Lower Eocene, developed mainly as continental strata, is known from northwestern Poland; Piwocki, 2004). Palaeontological datings show the presence of marine Eocene strata, from the oldest Lower?-Middle Eocene in the northwestern Poland (the Tanowo Formation), through to the most widely distributed Middle and Upper Eocene. The southern boundary of the present-day continuous Eocene occurrence, which is erosional (e.g., Piwocki, 2004), runs approximately along the northern slopes of the Lublin Upland and along a similar latitude in western Poland (Fig. 1A). South of this line, only scattered sites with glauconitic sands of uncertain age occur; they commonly lack palaeontological documentation, and their age is suggested to

*E-mail: ndgedl@cyf-kr.edu.pl

Received: February 6, 2014; accepted: April 12, 2014; first published online: May 12, 2014 be Eocene or Oligocene on the base of lithological correlation or radiometric dating of glauconite. The only exceptions are palaeontologically dated Eocene and Oligocene sands that occur in the vicinity of Tarnogród (Carpathian Foreland; Gedl, 2000; Myśliwiec and Śmist, 2006) and glauconitic sands that fill the Sołokija Graben at Roztocze (Fig. 1B). The latter structure, 2-3 km wide and $20 \mathrm{~km}$ long, was discovered by Kulczycka (1975) and later documented during geological mapping (Buraczyński and Krzowski, 1994; Cieśliński et al., 1994; Rzechowski, 1997). The Eocene succession of the Sołokija Graben was dated by Gaździcka (1994; calcareous nannoplankton) and Krzowski (1993; glauconite dating) in boreholes from the western part of the graben near Tomaszów Lubelski. Both methods gave similar results pointing to a Middle Eocene (Bartonian) age - calcareous nannoplankton zone NP16 and 39.5-42.2 \pm 3.0 myr absolute argon age of glauconite. Słodkowska (in Buraczyński and Rzechowski, 1998) dated organic-walled phytoplankton and suggested its Priabonian age in the upper, non-calcareous, part of the succession.

The present study focuses on dinoflagellate cysts from a complete sequence of sands from a central part of the Sołokija Graben. The succession, $33 \mathrm{~m}$ thick, drilled at Leliszka was sampled: twenty seven samples yielded rich and diverse marine dinoflagellate cyst assemblages analysed for 


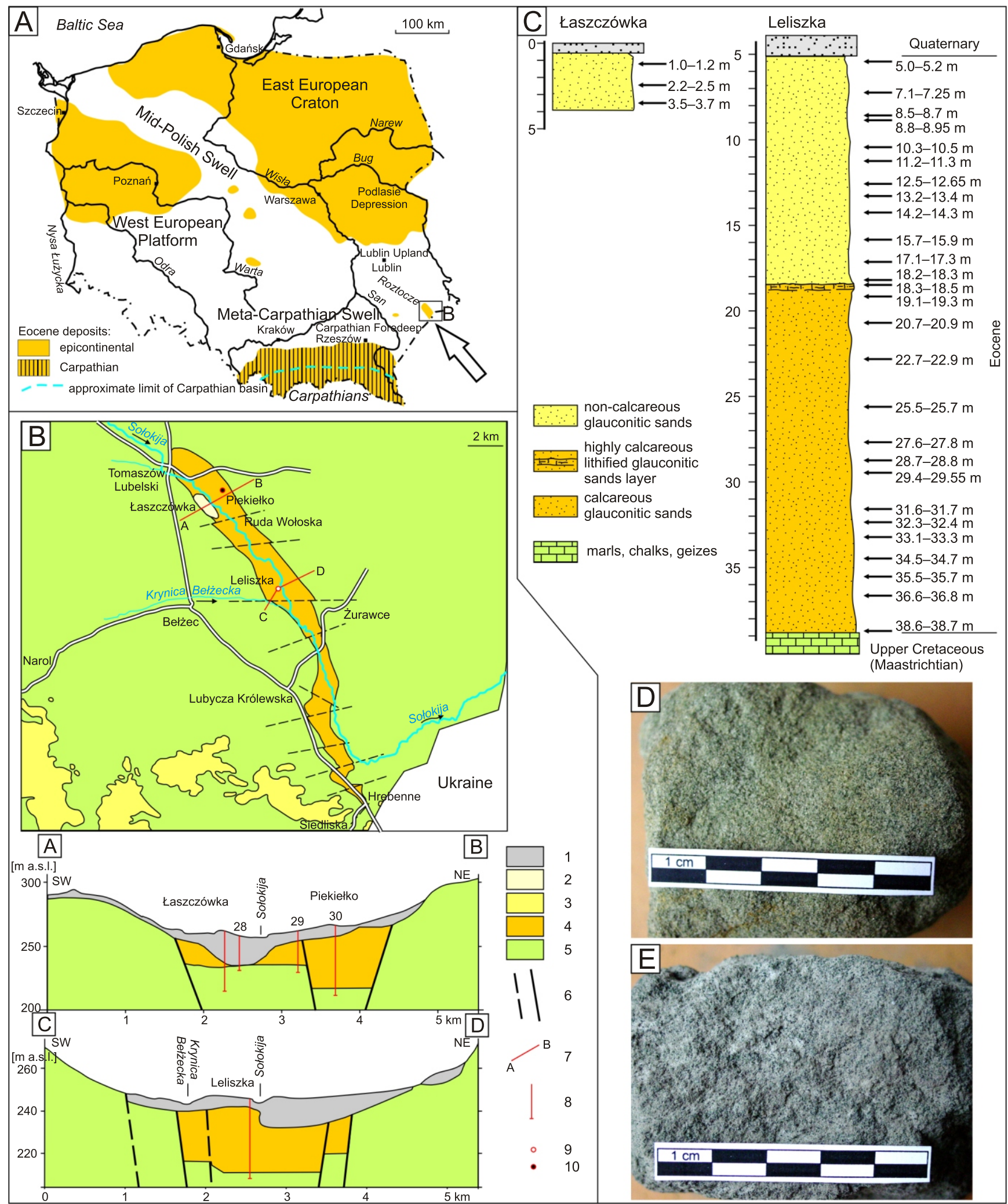

Fig. 1. Location of the boreholes studied and geology of the study area

A - location of the Sołokija Graben (arrowed) on the map with extent of the Middle-Upper Eocene deposits in Poland (based on Grabowska and Słodkowska, 1993; Piwocki, 2004; Słodkowska, 2004; Myśliwiec and Śmist, 2006); B - geological map of the Sołokija Graben (from Cieśliński et al., 1994, simplified): 1 - Quaternary, 2 - Pliocene, 3 - Miocene, 4 - Middle-Upper Eocene, 5 - Upper Cretaceous (Maastrichtian), 6 - faults, 7 - cross-section line, 8 - borehole, 9 - Leliszka borehole, 10 - Łaszczówka borehole; cross-section through the Sołokija Graben at Łaszczówka (A-B after Buraczyński et al., 1992, from Buraczyński and Krzowski, 1994, simplified); cross-section through the Sołokija Graben at Leliszka (C-D from Rzechowski and Kubica, 1995, simplified); C - Łaszczówka and Leliszka boreholes with the position of the samples studied; D - lithology of the Eocene succession in the basal part (depth $38.6 \mathrm{~m}$ ); $\mathbf{E}$ - lithology of the Eocene succession in the uppermost part (depth $5.1 \mathrm{~m}$ ) 
biostratigraphy. Their presence confirms earlier data pointing to an Eocene marine transgression that covered Roztocze and shows that southeastern Poland, a region believed to be emergent during the Paleogene, was at least partially covered by a brief marine incursion.

\section{GEOLOGICAL BACKGROUND}

The Lublin Upland and the Roztocze area are elevated structures in relation to the Carpathian Foredeep to the south, and the Podlasie Depression to the north. They represent a part of the Lublin Syncline that is located at the southeastern peripheries of the Mid-Polish Swell, a structure that was formed by inversion of the Mid-Polish Trough along the older, pre-Miocene fault systems (the Teisseyre-Tornquist Zone; e.g., Kutek, 2001) between the Precambrian East European Craton and the $\mathrm{Pa}$ leozoic (epi-Variscan) West European Platform (e.g., Ziegler, 1988; Fig. 1A) during the latest Cretaceous-Paleogene, with its final stage during the Neogene Neo-Alpine orogeny of Carpathians (e.g., Ney et al., 1974; Żelichowski, 1974; Krzywiec, 2006, 2007). Inversion was initiated by stress induced by northwards migrating plates of the Alps and Carpathians during their collisional phases. The earliest uplift movements took place during the Late Cretaceous-Paleocene but their precise age is not known. In its central part the Mid-Polish Trough is covered by Eocene deposits what suggests that its uplift ended before the Eocene (e.g., Krzywiec, 2006). The Paleogene succession in the southern part of the Mid-Polish Trough, which is built mainly of Upper Cretaceous strata (e.g., Hakenberg and Świdrowska, 2001) consists of the Lower Paleocene and Middle-Upper Eocene. This occurs mainly in the northern part of the Lublin Upland, whereas its central and southern parts are virtually devoid of strata of this age. Some isolated, poorly dated patchy deposits of presumably Eocene age in this area show that their present-day distribution is a result of erosion. The same refers to Roztocze which is virtually devoid of strata of these ages except of the Eocene succession in the Sołokija Graben (Fig. 1B; some isolated outliers believed to represent the Eocene have no palaeontological evidence; see Buraczyński and Krzowski, 1994). Erosion was also presumably partly responsible for removing Oligocene marine deposits, which occur as isolated inliers in the neighbouring Carpathian Foredeep near Tarnogród (Gedl, 2000). Erosion of marine Paleogene strata in southeastern Poland is supported by the occurrence of frequent reworked dinoflagellate cyst specimens in the Miocene of the Carpathian Foredeep and Roztocze (Gedl, 2012). The Miocene strata on Roztocze, genetically related to the Foredeep Basin, show a completely different development than the basinal facies of the latter basin. It comprises shallow-marine organodetrital and sandy facies and its thickness reaches only several tens of metres (e.g., Musiał, 1987; Buraczyński, 1997; Wysocka, 2002) compared to almost $2000 \mathrm{~m}$ of fine-grained siliciclastic deposits in the basinal part of the Foredeep Basin (e.g., Ney et al., 1974). These facies differences show that, during the Middle Miocene, Roztocze was already uplifted in relation to the main part of the Foredeep Basin.

\section{MATERIAL}

Two sites with Eocene strata within the Sołokija Graben have been studied: an exposure and a shallow borehole at Łaszczówka and a borehole at Leliszka.
Łaszczówka. Three samples were collected from a shallow hand-drilled borehole at Łaszczówka. The borehole was situated in the Sołokija River valley, north of the river (Fig. 1B). Here, Eocene greenish sands occur below a 1.0-1.5 m thick Quaternary cover, being locally exposed where Quaternary sands have been quarried away. A hand-drilled borehole reached the $4 \mathrm{~m}$ thick topmost part of the Eocene succession composed of lemon-greenish medium-grained, loamy, non-calcareous, quartz-glauconitic sands (Fig. 1C). The complete Eocene profile here, penetrated by the neighbouring Piekiełko-30 borehole, is $40 \mathrm{~m}$ thick (Buraczyński and Krzowski, 1994) so the succession studied presumably represents its topmost part.

Leliszka. A total of twenty seven samples were collected for the present study from a $33 \mathrm{~m}$ thick succession drilled at Leliszka. The samples were supplied to the author by Tadeusz Król (UMCS in Lublin); no closer examination of the core was possible by the author. The borehole was located on the western bank of the Sołokija River, ca. $1.2 \mathrm{~km}$ north of the Krynica Bełżecka (vel Źródło) River junction with the Sołokija River (see Rzechowski and Kubica, 1995; Fig. 1B). The Eocene succession studied rests on Upper Maastrichtian marl (see Gaździcka, 1994). It consists of fine- to medium-grained quartz-glauconitic loamy sands, which in their lower part are calcareous (interval 18.3-38.0 m; Fig. 1D), whereas in the upper part they are non-calcareous (Fig. 1C). The uppermost part of the calcareous interval of some $20-30 \mathrm{~cm}$ thick (sample 18.3-18.5 m) is paler coloured (beige to pale grey) than the sands below and above; the sand at this depth is more lithified and has a higher carbonate content than the strata below (it can presumably be correlated with a marly limestone layer, up to $20 \mathrm{~cm}$ thick, described from the top of the calcareous sands of the Sołokija succession; e.g., Cieśliński and Rzechowski, 1993). Muddy sands just above (sample 18.2-18.3 m and above) are fine-grained, easily disintegrable and contain no carbonates. They show grey-greenish colouration, which becomes intensly green in its upper part, presumably due to a higher content of glauconite, and lemon-green at the top (samples: 8.8-8.95 m, 7.1-7.25 m, 5.0-5.2 m; Fig. 1E). Sample positions are shown in Figure $1 \mathrm{C}$.

\section{METHODS}

The samples were processed in the micropalaeontological laboratory of the Institute of Geological Sciences, Polish Academy of Sciences, Kraków. The palynological procedure applied included $38 \%$ hydrochloric-acid $(\mathrm{HCl})$ treatment, $40 \%$ hydrofluoric-acid (HF) treatment, heavy-liquid $\left(\mathrm{ZnCl}_{2}+\mathrm{HCl}\right.$; density $2.0 \mathrm{~g} \cdot \mathrm{cm}^{-3}$ ) separation, ultrasound for $10-15 \mathrm{~s}$ and sieving at $10 \mu \mathrm{m}$ on a nylon mesh. Nitric-acid $\left(\mathrm{HNO}_{3}\right)$ treatment was not applied.

The quantity of rock processed was $120 \mathrm{~g}$ for each sample. Palynological slides were made from each sample using glycerine jelly as a mounting medium. The rock samples, palynological residues and slides are stored in the collection of the Institute of Geological Sciences, Polish Academy of Sciences, Kraków.

Dinoflagellate cysts were analysed for their diversity; at least 300 cysts were counted except for samples from depths 10.3-10.5, 8.8-8.95 and 5.0-5.2 m, which contain impoverished assemblages. On this basis, the Shannon-Weaver diversity index $\left(H^{\prime}\right)$ was calculated as: $H^{\prime}=-\Sigma ? p_{i} \ln \left(p_{i}\right)$ where $p_{i}$ is the relative abundance of each taxon; the Shannon-Weaver index was expressed as: $\mathrm{e}^{H^{\prime}}$. Palynofacies elements were counted up to 500 . 


\section{RESULTS}

ŁASZCZÓWKA

Samples from this site appeared to be barren; they contain no palynological organic matter.

\section{LELISZKA BOREHOLE}

All samples from the Leliszka borehole contain palynological organic matter. A characteristic feature of almost all samples is a high proportion of aquatic palynomorphs, mainly marine dinoflagellate cysts (Appendix $1^{*}$ ), which frequently attain $30-70 \%$. The latter are commonly mechanically damaged; this refers especially to large specimens, which usually occur as isolated processes or cyst fragments only.

Palynofacies. Palynofacies composition is generally uniform throughout the succession studied except in its uppermost part. Interval $17-38 \mathrm{~m}$ is characterized by a frequent occurrence of dinoflagellate cysts, which are the most common among palynomorphs; their percentage ranges from 30 to over $70 \%$. They are associated with small-sized palynodebris represented by black opaque and dark brown phytoclasts and cuticle remains, sporomorphs (mainly bisaccate pollen grains) and other aquatic palynomorphs such as foraminifera, Pterospermella, Tasmanites, Cymatiosphaera, Paucilobimorpha. Exceptions within the 17-38 $\mathrm{m}$ interval are samples from the depth of $20.0-22.9 \mathrm{~m}$, where the dinoflagellate cyst proportion decreases to a few percent, and a major palynofacies component is structureless particles. The latter occur in a higher percentage once again in a sample from the depth 18.3-18.5 m (the topmost part of the calcareous interval) but here dinoflagellate cysts represent almost $60 \%$.

The interval from 11.2 to $15.9 \mathrm{~m}$ is dominated by small cuticle remains and dark brown phytoclasts; the dinoflagellate cyst proportion is 20 (in the lower part of this interval) to $40 \%$ (upper part). A significant change in palynofacies composition is noted in two samples from the depths $10.3-10.5$ and 8.8-8.95 m; they contain very low amounts of palynological organic matter, which consists of large black phytoclasts and pollen grains; dinoflagellate cysts are rare in both samples: they are up to $2 \%$ in the sample from depth $10.3-10.5 \mathrm{~m}$, and $1 \%$ in the sample from depth 8.8-8.95 $\mathrm{m}$. Two higher samples (8.5-8.7 and 7.1-7.25 m) contain much higher amounts of palynological organic matter; their characteristic feature is a high percentage of aquatic algae (e.g., Tasmanites, Pterospermella, Cymatiosphaera, Leiosphaeridia) which, while occuring in almost all other samples, here reach proportions of $10 \%$ $(8.5-8.7 \mathrm{~m})$ and $30 \%(7.1-7.25 \mathrm{~m})$. The dinoflagellate cyst percentage from these depths is $30-40 \%$. The topmost sample (5.0-5.2 m) contains, as do samples from depths 10.3-10.5 and $8.8-8.95 \mathrm{~m}$, low amounts of palynological organic matter, which also consists of large black phytoclasts and pollen grains; dinoflagellate cysts represent a few percent there.

Dinoflagellate cyst assemblages. Dinoflagellate cyst assemblages from most of the succession studied show a generally uniform composition; only the uppermost samples yielded significantly different assemblages (Appendix 2; Figs. 2-5).

Samples from the lower, calcareous interval (18.3-38.7 m), yielded rich and taxonomically diverse assemblages (with a Shannon-Weaver index usually higher than 18) characterized by the predominance of chorate gonyaulacoids (mainly
Spiniferites; ratios of Dapsilidinium, Enneadocysta, Systematophora, Operculodinium, Areosphaeridium, Lingulodinium vary between the samples) and proximate Batiacasphaera (Figs. 2 and 4). Characteristically, these chorate gonyaulacoid-dominated assemblages are virtually devoid of Homotryblium, which occurs in a relatively high proportion in a sample from the depth 35.5-35.7 m only; it occurs in other samples just as single specimens. Another characteristic feature is the rare occurrence of peridinioids. These, although present in all samples (mainly Deflandrea phosphoritica, Wetzeliella articulata, $W$. eocaenica, Charlesdowniea spp.), rarely reach higher proportions. They are most frequent at the depth 36.6-36.8 $\mathrm{m}$ (Deflandrea phosphoritica) and particularly at the depth 25.5-31.7 $\mathrm{m}$ where Lentinia serrata forms an acme in the topmost sample (25.5-25.7 $\mathrm{m}$ ) representing almost half of the whole assemblage.

Taxonomically the diversity is the highest in the depth interval 22.7-35.7 $\mathrm{m}$ where the Shannon-Weaver index equals 20 or higher; the highest diversity was noted at the depth 34.5-34.7 m (Shannon-Weaver index over 33). Samples with the highest diversity yielded rare Impagidinium specimens. Higher, the Shannon-Weaver index drops slightly down to 15 in the topmost sample from the depth $18.3-18.5 \mathrm{~m}$.

The dinoflagellate cyst assemblages from the basal part of the upper, non-calcareous interval (depth 15.7-18.3 m), are similar to those from the calcareous interval: they are composed mainly of chorate gonyaulacoids but without Homotryblium; peridinioids are also relatively rare (Figs. 3 and 4). Thus, there is no change in the dinoflagellate cyst composition associated with the transition between calcareous and non-calcareous sands at the depth of $18.3 \mathrm{~m}$. However, the distribution of some taxa in the succession studied may suggest that part of the dinoflagellate cysts above the depth $18.3 \mathrm{~m}$ is reworked from the basal interval (see Biostratigraphy section). Higher samples also contain similar gonyaulacoid-dominated assemblages though their diversity decreases; Homotryblium occurs relatively frequently in samples from the depths 14.2-14.3 and $12.5-12.65 \mathrm{~m}$. The diversity of dinoflagellate cyst assemblages is lower than in the calcareous interval; the Shannon-Weaver index shows a gradual decline from almost 21 in the basal sample $(18.2-18.3 \mathrm{~m})$ to almost 11 at the depths $12.5-12.65$ and $11.2-11.3 \mathrm{~m}$. However, assemblages from basal interval of the non-calcareous section might be enriched in reworked specimens from the calcareous interval (see Biostratigraphy section).

A significant change in dinoflagellate cyst assemblages takes place in samples from depths $10.3-10.5$ and 8.8-8.95 m (these samples contain also very low amounts of palynological organic matter composed of large cuticle fragments and pollen grains): rare dinoflagellate cysts are dominated by Deflandrea. The diversity of the assemblages in these two samples drops drastically: the Shannon-Weaver index is below 3 there. A similar assemblage (and the same palynofacies) is noted from the topmost sample from the depth 5.0-5.2 m; the Shannon-Weaver index is also low at 4.

These two intervals with dinoflagellate cysts dominated by Deflandrea are separated by an interval (samples 8.5-8.7 and 7.1-7.25 m) with rich and diverse assemblages (the Shannon-Weaver index is over 13) characterized by a predominance of chorate gonyaulacoids and a rarity of peridinioids. Homotryblium floripes is frequent in both samples.

Additionally, a shark tooth was found during sample processing in a sample from the depth $14.2-14.3 \mathrm{~m}$. 

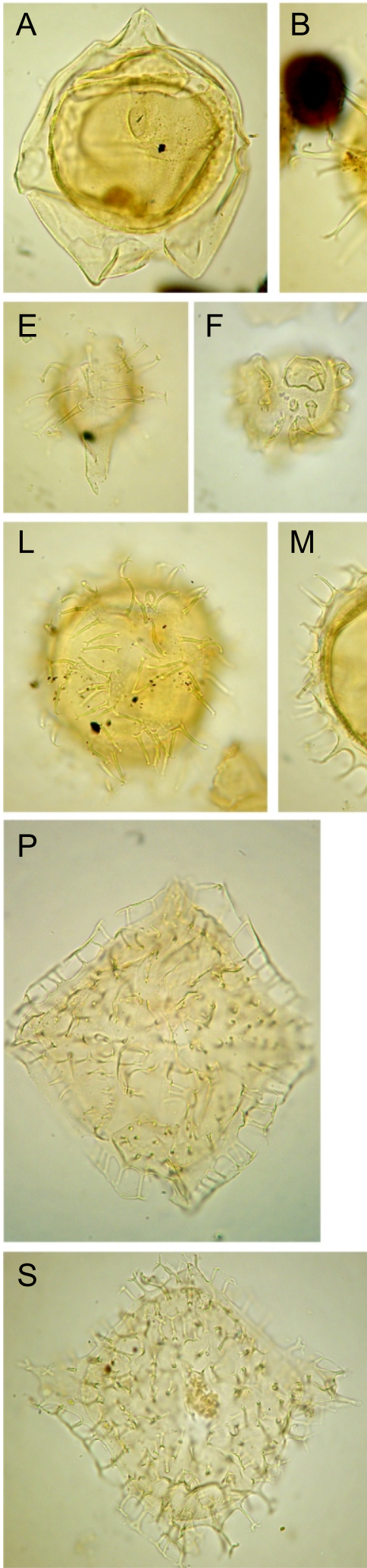
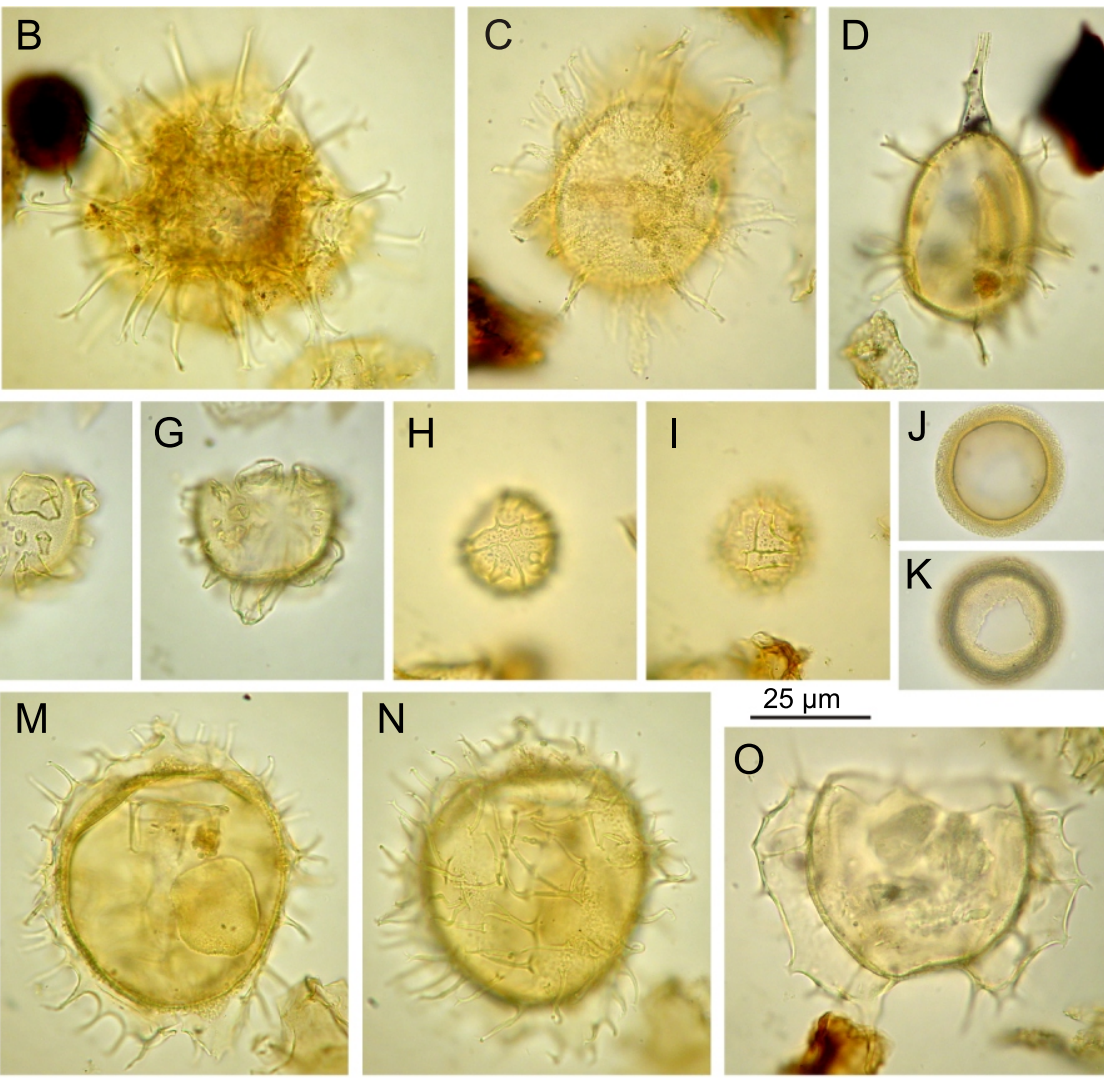

$25 \mu \mathrm{m}$
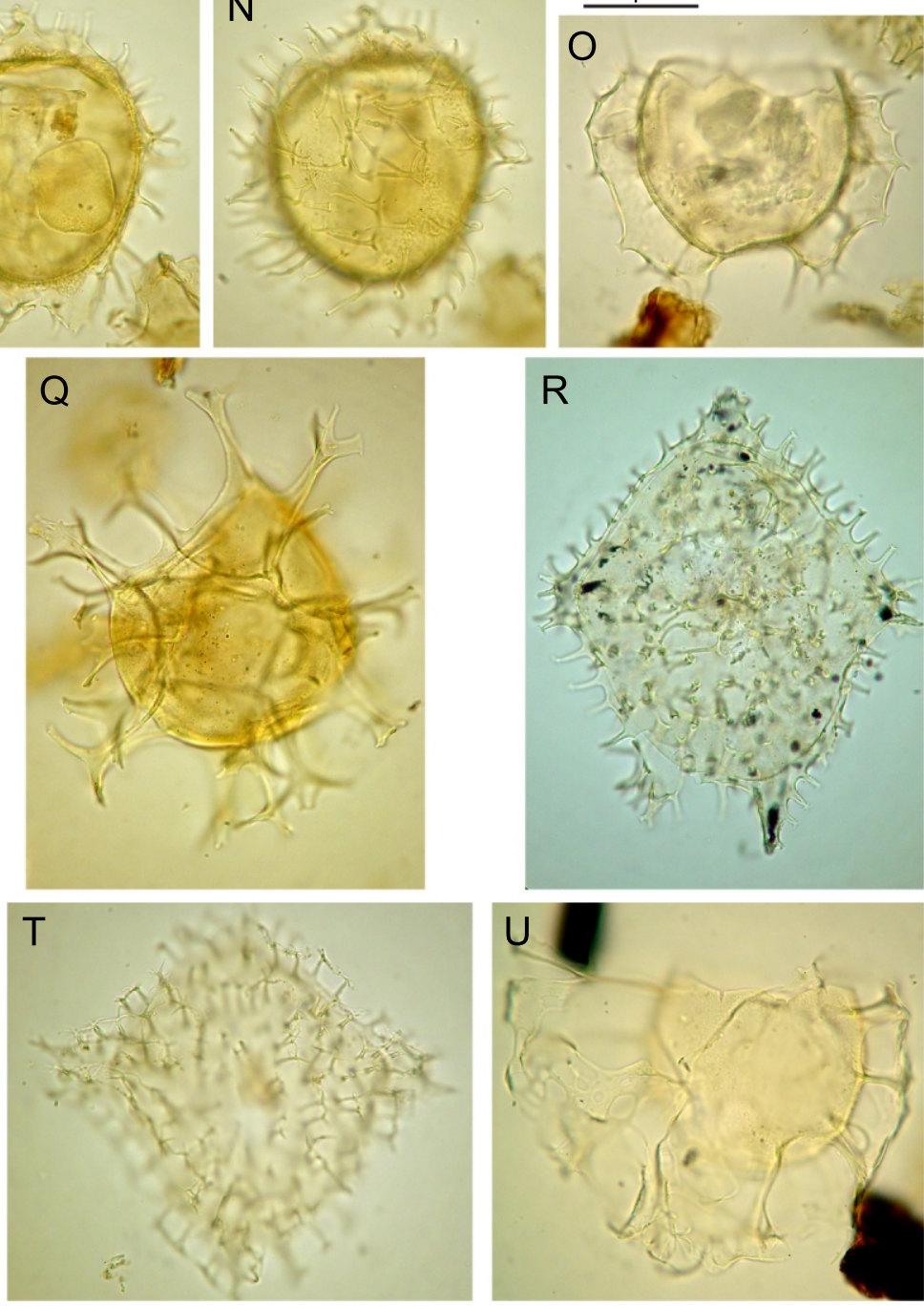

Fig. 2. Dinoflagellate cysts from the Leliszka borehole: species characteristic of the basal, calcareous interval (depth 18.3-38.7 m)

A - Deflandrea arcuata (36.6-36.8 m); B - Operculodinium divergens (36.6-36.8 m); C - Fibrocysta radiata (33.1-33.3 m); D - Spiniferella cornuta (33.1-33.3 m); E - Diphyes colligerum (36.6-36.8 m); F, G - Hystrichokolpoma globulus (36.6-36.8 m; same specimen, various foci); H, I - Corrudinium incompositum (31.6-31.7 m; same specimen, various foci); J, K - Tectatodinium pellitum (33.1-33.3 m; same specimen, various foci); L-N - Wetzeliella eocaenica (36.6-36.8 m; same specimen, various foci); $\mathbf{O}$ - Chiropteridium eocaenicum (34.5-34.7 m); $\mathbf{P}$ - Charlesdowniea coleothrypta (33.1-33.3 m); Q - Spiniferites pseudofurcatus (36.6-36.8 m); $\mathbf{R}$ - Wetzeliella articulata (38.6-38.7 m); $\mathbf{S}$, T - Charlesdowniea variabilis (35.5-35.7 m); U - Glaphyrocysta semitecta (33.1-33.3 m) 



$25 \mu \mathrm{m}$

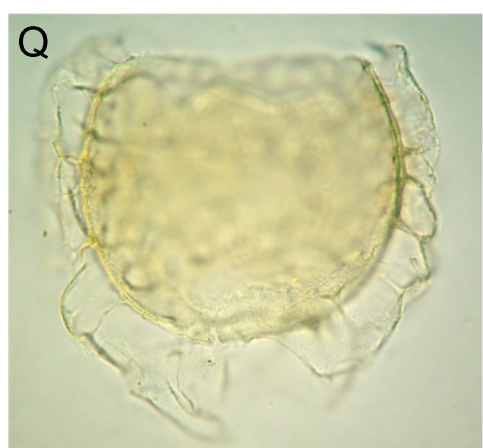

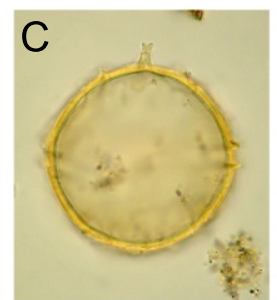

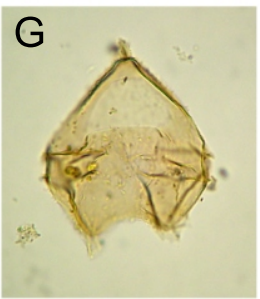

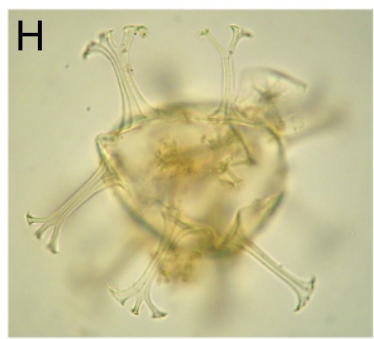
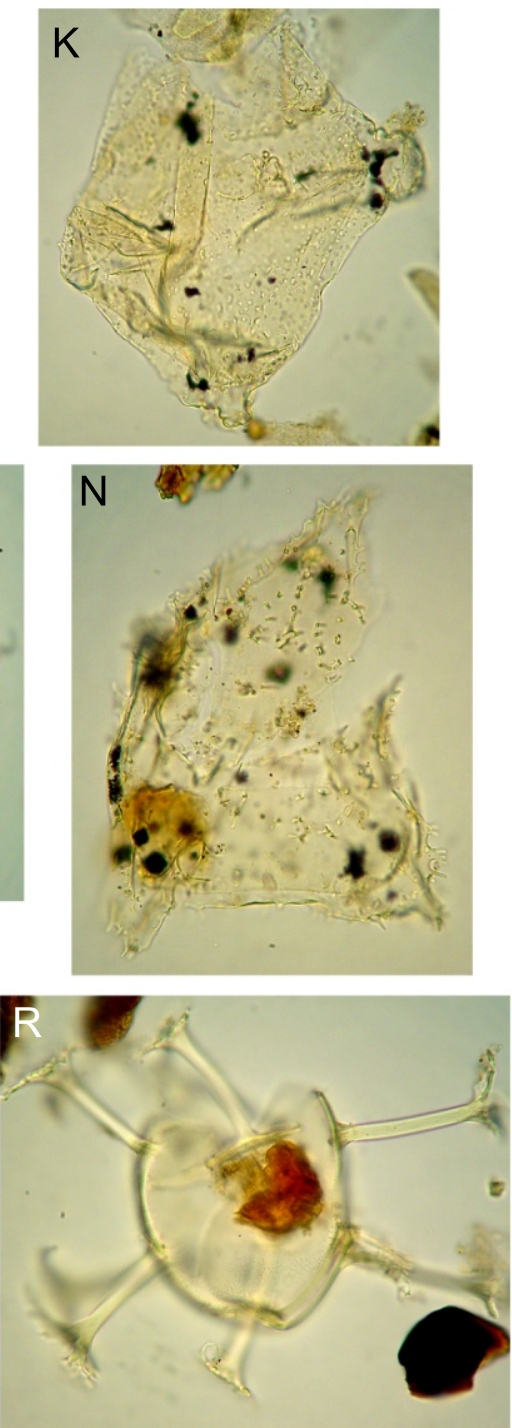

$E$
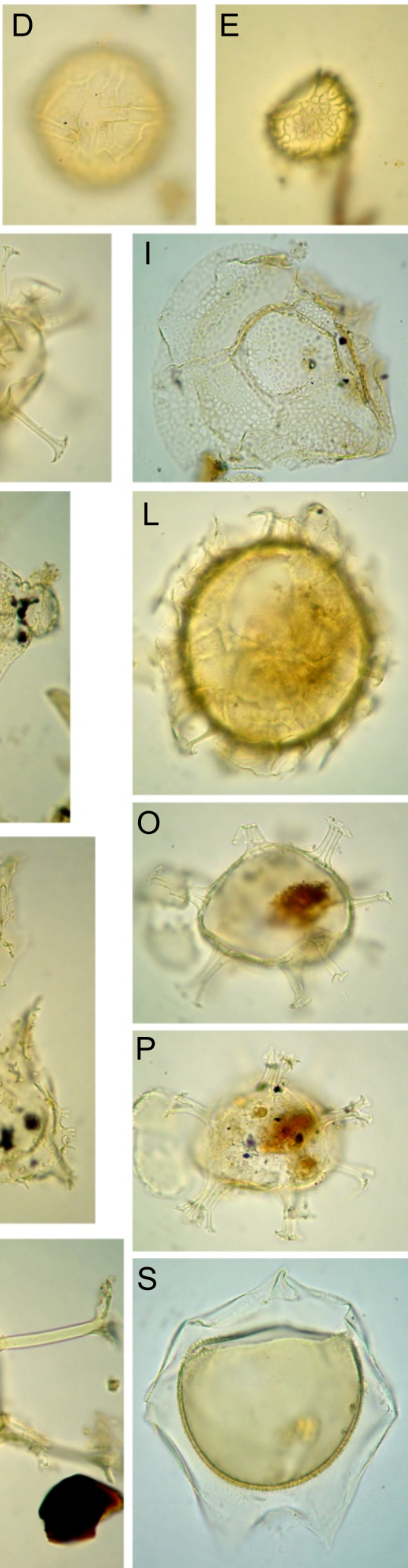

Fig. 3. Dinoflagellate cysts from the Leliszka borehole: species characteristic of the upper, non-calcareous interval $(5.0-18.5 \mathrm{~m})$

A - Phthanoperidinium comatum (14.2-14.3 m); B-D - Cribroperidinium giuseppei (same specimen, various foci; 14.2-14.3 m); E - Cerebrocysta bartonensis (11.2-11.3 m); F - Hystrichostrogylon coninckii (8.5-8.7 m); G - Lentinia serrata (18.2-18.3 m); H - Homotryblium floripes (8.5-8.7 m); I - Heterelaucacysta porosa (8.5-8.7 m); J - Wetzeliella simplex (14.2-14.3 m); K - Rhombodinium perforatum (8.5-8.7 m); L - Samlandia chlamydophora (12.5-12.65 m); M - Cordosphaeridium funiculatum (15.7-15.9 m); N - Wetzeliella simplex (15.7-15.9 m); O, P - Homotryblium floripes (same specimen, various foci, 12.5-12.65 m); $\mathbf{Q}$ Membranophoridium aspinatum (7.1-7.25 m); $\mathbf{R}$ - Areosphaeridium michoudii (15.7-15.9 m); $\mathbf{S}$ - Deflandrea phosphoritica $(5.0-5.2 \mathrm{~m})$ 


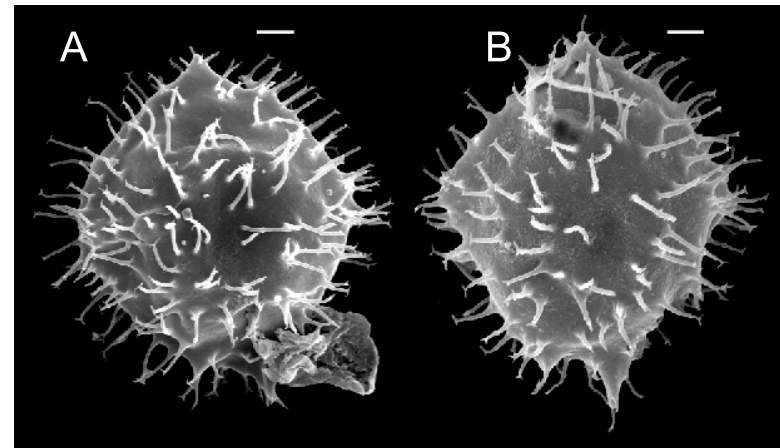

E

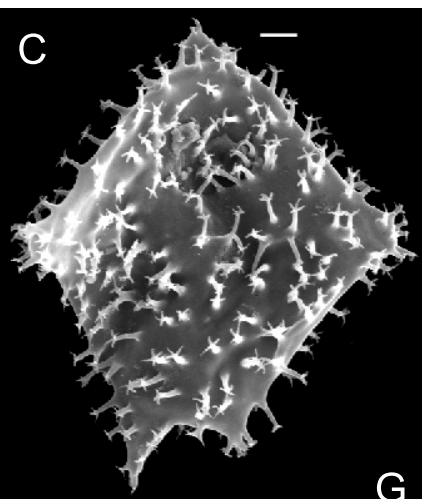

G

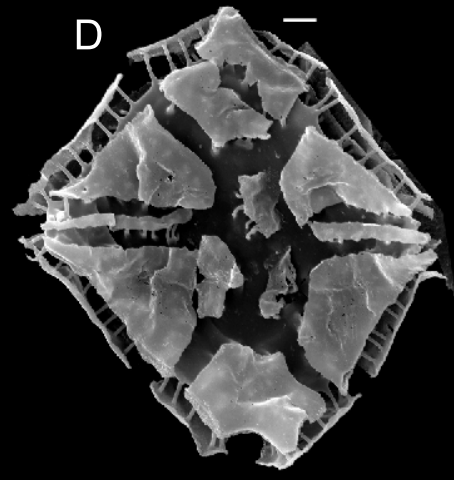

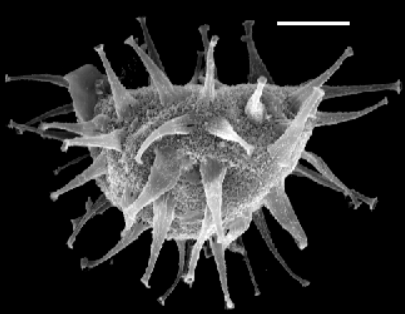
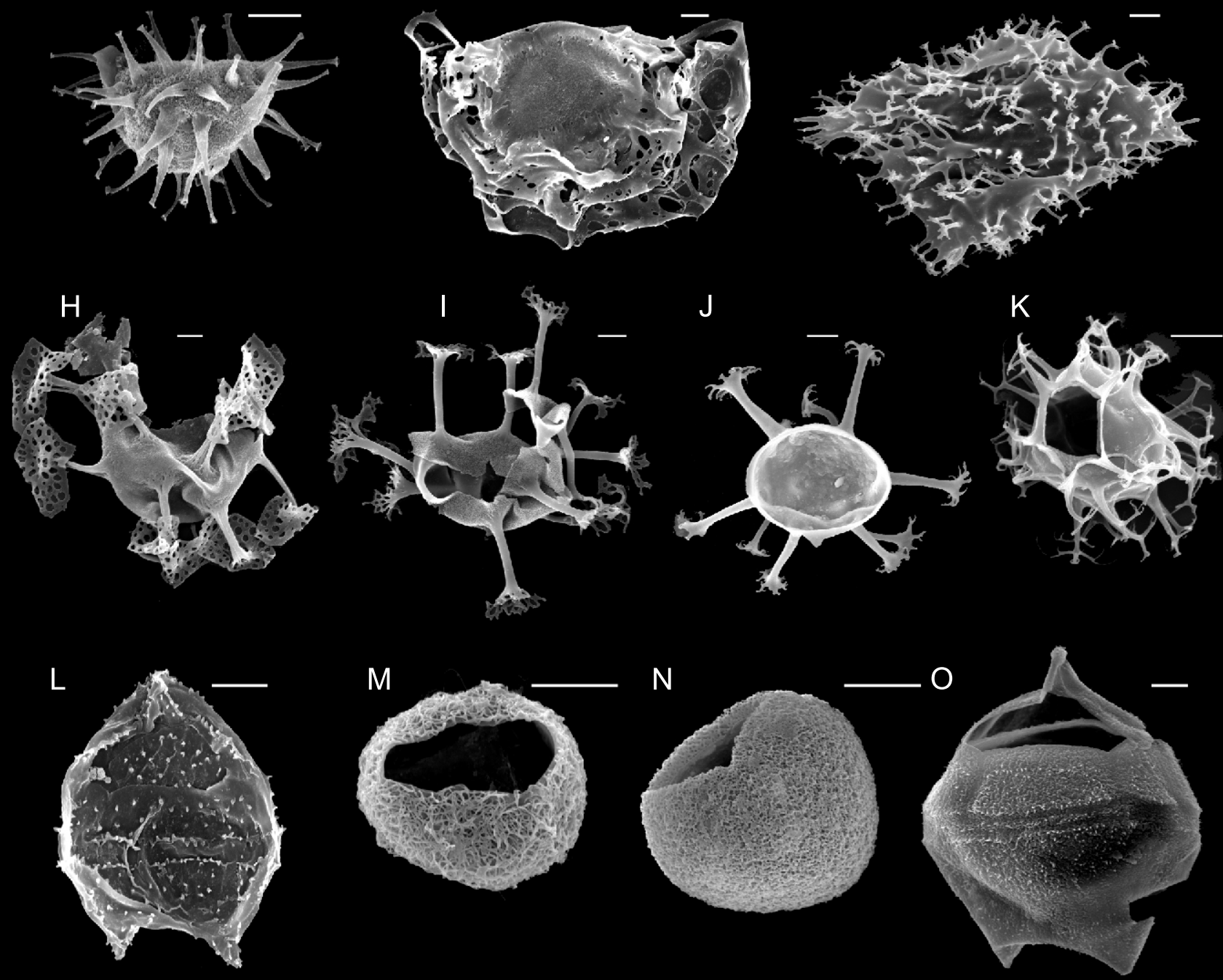

Fig. 4. Dinoflagellate cysts from the Leliszka borehole, SEM microphotographs

A, B - Wetzeliella eocaenica (A: 33.1-33.3 m; B: 34.5-34.7 m); C - Wetzeliella articulata (33.1-33.3 m); D - Charlesdowniea coleothrypta (33.1-33.3 m); E - Dapsilidinium pseudocolligerum (33.1-33.3 m); F - Glaphyrocysta semitecta (33.1-33.3 m); G - Charlesdowniea variabilis (33.1-33.3 m); H - Areosphaeridium diktyoplokum (33.1-33.3 m); I - Areosphaeridium michoudii (33.1-33.3 m); J - Homotryblium aculeatum (34.5-34.7 m); K - Spiniferites ramosus (33.1-33.3 m); L - Lentinia serrata (29.4-29.55 m); M - Batiacasphaera sp. (29.4-29.55 m); N - Tectatodinium pellitum (31.6-31.7 m); O - Deflandrea phosphoritica (34.5-34.7 m); scale bars are $10 \mu \mathrm{m}$ 

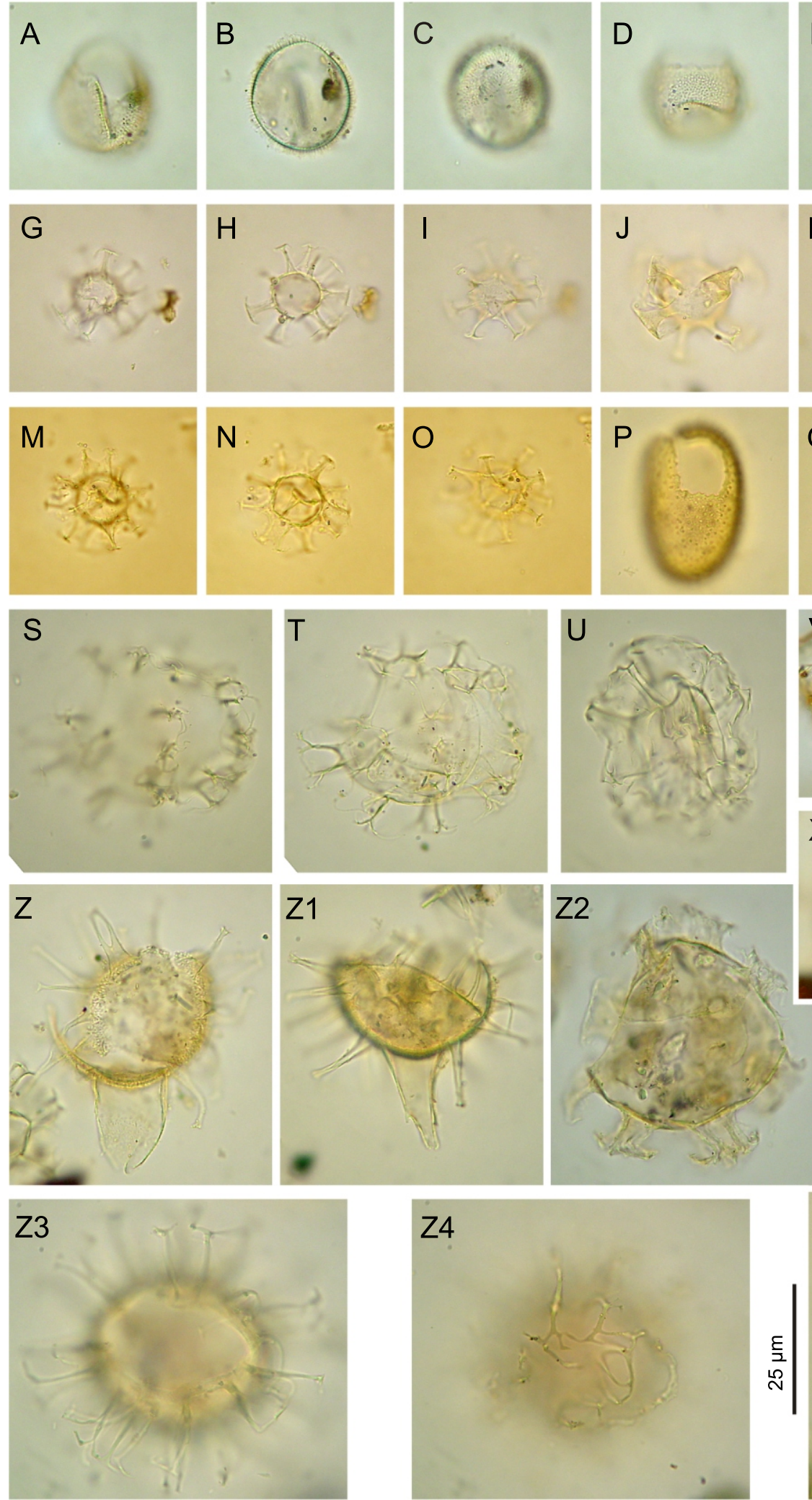
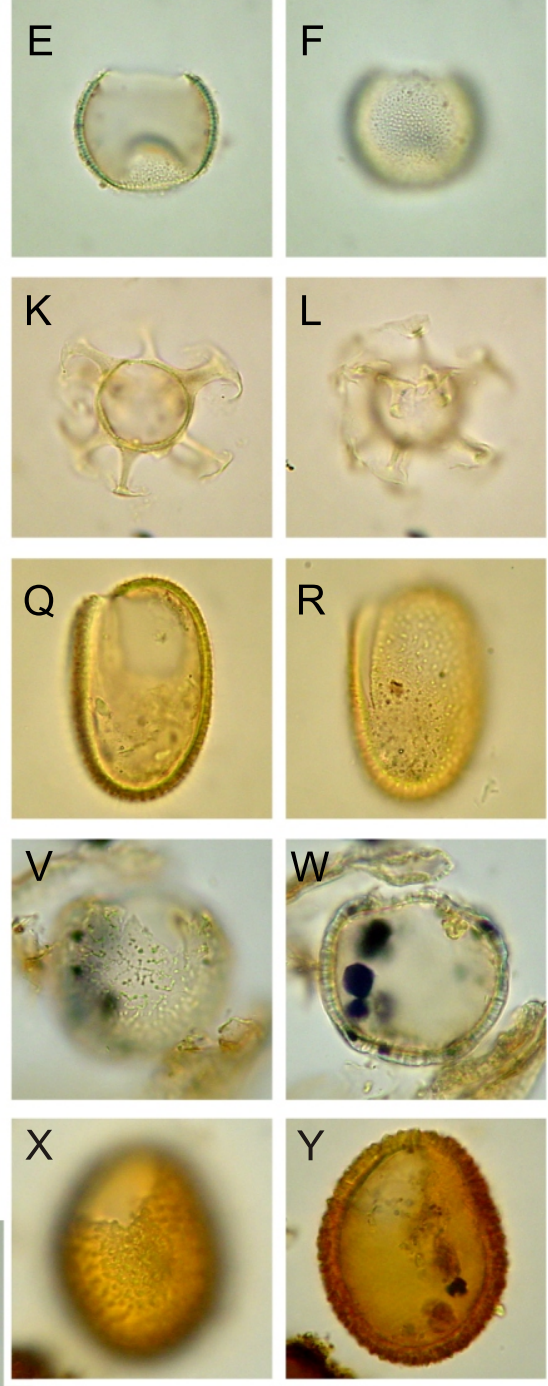

Z5

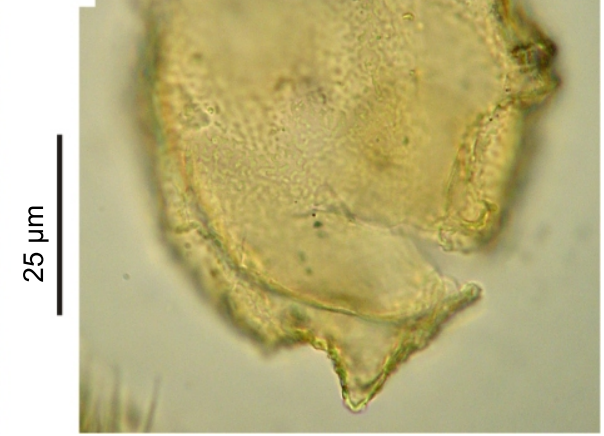

Fig. 5. Dinoflagellate cysts from the Leliszka borehole

A-C - Batiacasphaera hirsuta (same specimen, various foci, 38.6-38.7 m); D-F - Batiacasphaera sp. (same specimen, various foci, 38.6-38.7 m); G-I - Cordosphaeridium minimum: specimen with thin processes (same specimen, various foci, $38.6-38.7 \mathrm{~m}$ ); J-L Cordosphaeridium minimum: specimen with thick processes terminated with massive platforms (same specimen, various foci,); $\mathbf{M}-\mathbf{O}-$ Cordosphaeridium minimum: specimen with thin processes united proximally by high ridges, distally terminated by small expansions (same specimen, various foci, 38.6-38.7 m); P-R - Pyxidiella? sp. (same specimen, various foci, 34.5-34.7 m); S, T - Cannosphaeropsis? sp. (same specimen, various foci, 25.5-25.7 m); U - Ectosphaeropsis? sp. (7.1-7.25 m); V, W - Elytrocysta? sp. (same specimen, various foci, 34.5-34.7 m); X, Y - Pyxidinopsis? sp. (same specimen, various foci, 32.3-32.4 m); Z - Diphyes cf. ficusoides (25.5-25.7 m); Z1 - Diphyes colligerum (25.5-25.7 m); Z2 - Cordosphaeridium cf. inodes (34.5-34.7 m); Z3, Z4 - Cleistosphaeridium cf. placacanthum (22.7-22.9 m); Z5 - Dracodinium cf. rhomboideum (33.1-33.3 m) 


\section{INTERPRETATION}

\section{BIOSTRATIGRAPHY}

The Leliszka borehole succession yielded rich dinoflagellate cyst assemblages, which allow its dating. Although many species determined have long stratigraphical ranges, typical of the Eocene-Oligocene, some have shorter ranges being thus good age-indicators (Fig. 6).

Species with well-established stratigraphical ranges that occur throughout the whole succession studied include Areosphaeridium michoudii and Operculodinium divergens. The former is known from the Ypresian to basal Priabonian of the North Sea (Bujak, 1994) whereas O. divergens occurs in the Bartonian-Middle Rupelian (Williams et al., 1993). Their co-occurrence suggests a Bartonian-lowermost Priabonian age of the Leliszka borehole succession.

Dinoflagellate cyst assemblages from the basal, calcareous part of the Leliszka borehole succession (18.3-38.7 m) are generally similar; they show high taxonomical richness (Fig. 7). This suggests that this interval was deposited during a single sedimentary event. Many species occur in the basal calcareous part; their scattered occurrences in the upper, non-calcareous part $(5.0-18.3 \mathrm{~m})$ are presumably the result of reworking.

The Bartonian age of the basal, calcareous part is based on the occurrence of Chiropteridium eocaenicum, Charlesdowniea variabilis, Enneadocysta arcuata, Enneadocysta multicornuta, Cerebrocysta bartonensis, Corrudinium incompositum, and Lentinia serrata (Fig. 6).
Chiropteridium eocaenicum occurs in the basal part, up to the depth 25.5-38.7 $\mathrm{m}$ (higher, only a single, presumably reworked specimen was found at the depth 18.2-18.3 m) - this species was described from the Bartonian (Heilmann-Clausen and Simaeys, 2005; rare specimens have been found also in the Priabonian); Vasilyeva (2013) reported it from the upper part of the Bartonian of Kazakhstan.

Charlesdowniea variabilis occurs in the same interval as does $C$. eocaenicum (25.5-38.7 m); this species was described by Bujak (1980) from the Lower Barton Beds, England, correlated by Aubry (1986) with the topmost part of the NP16 Zone, i.e., the basal Bartonian (Berggren et al., 1995). According to Bujak et al. (1980) the total range of C. variabilis in southern England is limited to the uppermost Lutetian-Bartonian, i.e., the upper part of the NP16 Zone to the NP17 Zone (Aubry, 1986).

Enneadocysta arcuata (occurring in the lower part of the Leliszka succession up to the depth of $17.1 \mathrm{~m}$ ) and Enneadocysta multicornuta (occurring in 18.3-36.8 m interval; a single specimen occurs also in the topmost part at the depth of 8.5-8.7 $\mathrm{m}$ ) have their lowermost occurrences in the basal Bartonian (Bujak, 1976).

Rare specimens of Cerebrocysta bartonesis occur throughout most of samples studied; its lowest occurrence is noted in the sample from depth $36.6-36.8 \mathrm{~m}$, whereas its highest occurrence is noted in the sample from depth $8.5-8.7 \mathrm{~m}$. According to Bujak et al. (1980) this species appeared for the first time in the earliest Bartonian and disappeared in the Late Bartonian.

Corrudinium incompositum, which occurs throughout the whole section studied, has its first appearance, like $C$. bartonensis, in the earliest Bartonian (Bujak et al., 1980).

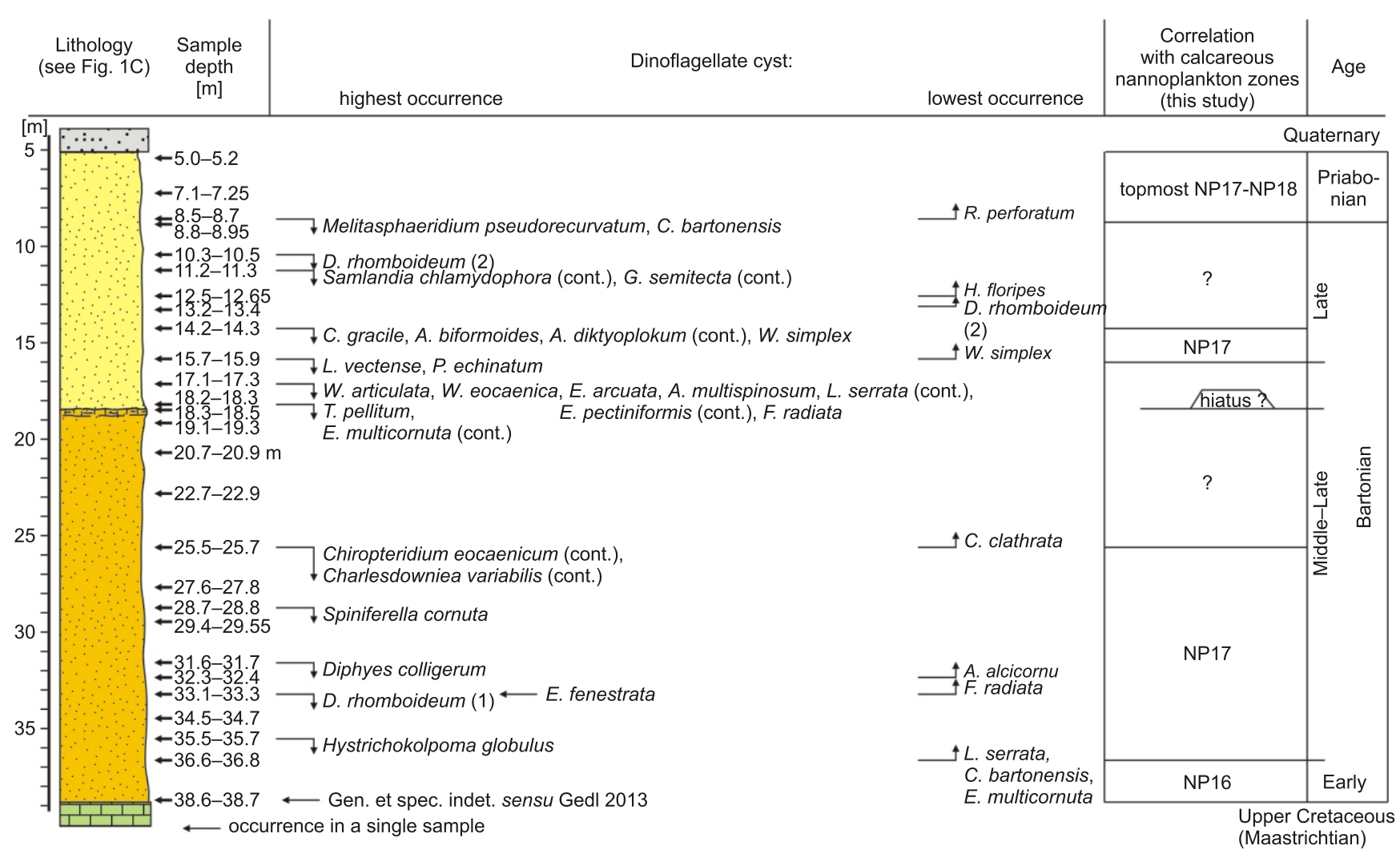

Fig. 6. Biostratigraphy of the Eocene succession of the Leliszka borehole

Highest and lowest occurrence data of selected species from the material studied; (1) and (2) by Dracodinium rhomboideum refer to two consistent occurrences of this species 


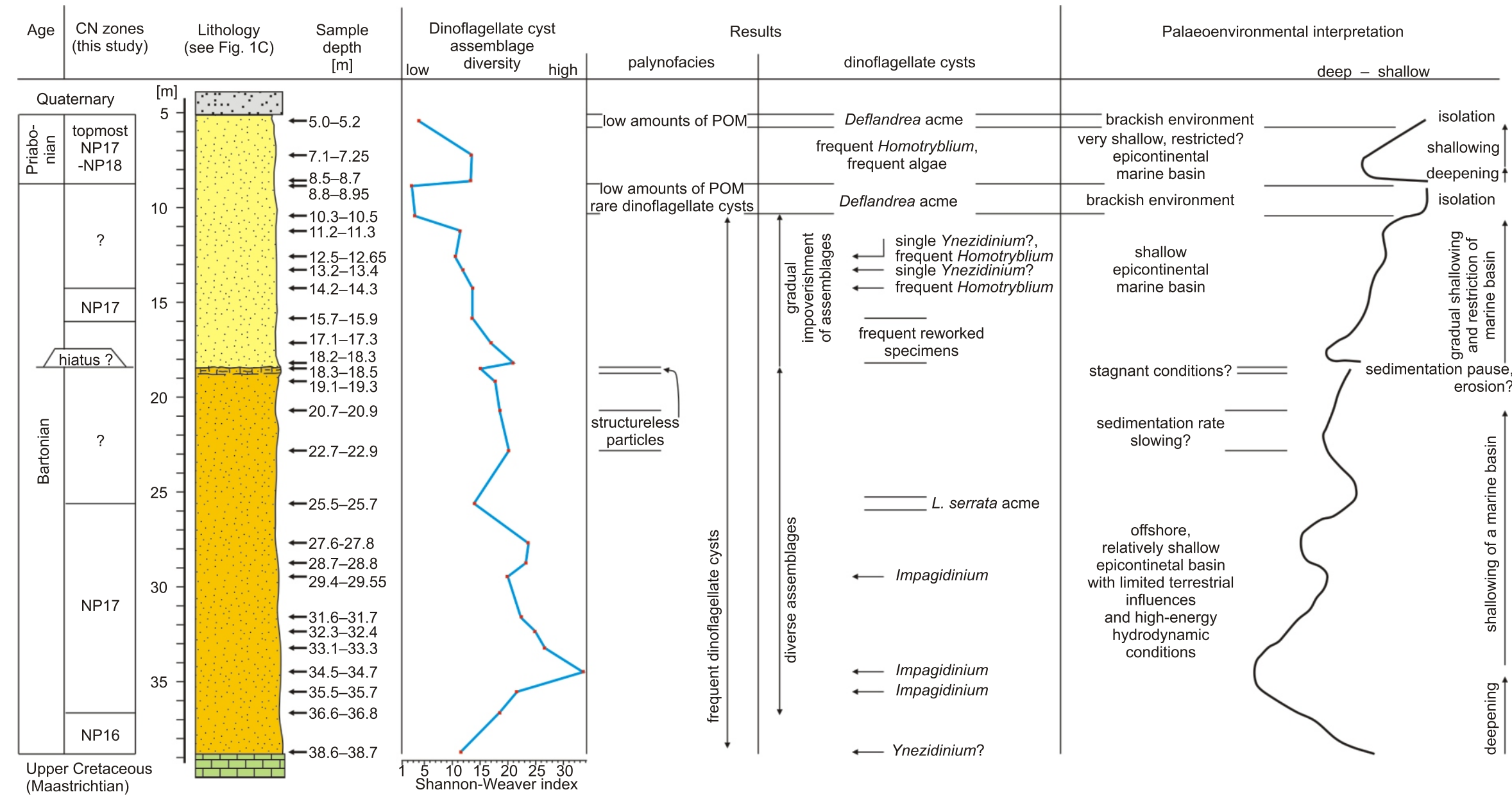

Fig. 7. Palaeoeonvironmental reconstruction of the Sołokija succession in the Leliszka borehole 
Lentinia serrata occurs in the calcareous part (except for the basal sample from the depth 38.6-38.7 $\mathrm{m}$ ) and in the basal part of the non-calcareous interval up to the depth $17.1 \mathrm{~m}$ (higher, a single specimen was found at the depth 12.5-12.65 $\mathrm{m}$ ); the presence of this species suggests the youngest age of all species noted above: $L$. serrata is believed to have appeared for the first time in mid latitudes during the Middle Bartonian (Bujak et al., 1980). Williams et al. (2004) dated this event as $40 \mathrm{Ma}$ and correlated it with middle part of Chrone 18. Berggren et al. (1995), in turn, correlated this age with the basal part of the NP17 Zone. Correlation of the lower part of the Leliszka succession (above $36.8 \mathrm{~m}$ ) with the Middle-Upper Bartonian can be confirmed by the occurrence of a single specimen of Enneadocysta fenestrata in the sample from depth 33.1-33.3 m; Bujak (1976) described this species from the upper part of the Middle Barton Beds and the Upper Barton Beds - Aubry (1986) correlated this interval with the NP17 Zone, i.e., the Middle and Upper Bartonian (Berggren et al., 1995).

A lack of Lentinia serrata in the lowermost sample (38.6-38.7 $\mathrm{m}$ ) may indicate that the $2 \mathrm{~m}$ thick basal interval represents the lower part of Bartonian, that may be correlated with the topmost part of the NP16 Zone (see Berggren et al., 1995). This interpretation can be supported by the occurrence of Gen. et spec. indet. sensu Gedl 2013 described by the author from strata of presumably Lower Bartonian age (Gedl, 2013).

Some other species found in the basal part of the Leliszka succession are known from deposits older than the Bartonian. But their frequent and regular occurrence in the material studied suggests that they are in situ there.

Wetzeliella eocaenica occurs throughout the whole calcareous interval; this species was described by Agelopoulos (1967) from Eocene clay at Heiligenhafen (dated as Lower and Upper Eocene; see also Agelopoulos, 1964), but it is known mainly from Lower Eocene strata (Caro, 1973, as W. pachyderma; lakovleva in Andreeva-Grigorovich et al., 2011). Vasilieva (in Andreeva-Grigorovich et al., 2011) reported it also from Bartonian.

Fibrocysta radiata occurs in the middle and upper part of the calcareous interval; it was described by Morgenroth (1966) from the Lower Eocene of north Germany and Belgium; Köthe and Piesker (2007) reported it from Ypresian-Lutetian of north Germany. These data may suggest that $F$. radiata is reworked, but this species was reported from the Popiele Beds in the Polish Carpathians dated as Lower Bartonian (sample Kns3; Gedl, 2013).

Hystrichokolpoma globulus (occurring in the basal part, 35.5-36.8 $\mathrm{m}$ ) is another species that is known from strata older than the Bartonian. It was described by Michoux (1985) from the topmost part of the Ypresian. But Heilmann-Clausen and Simaeys (2005) noted presence of this species also in the Bartonian.

The sample from the depth 25.5-25.7 m yielded two specimens of Hemiplacophora semilunifera. The range of this species is believed to be restricted to the Priabonian in the northern hemisphere (Williams et al., 2004), which contradicts the Bartonian age-interpretation of the basal part of the Leliszka succession. But in the high-latitudes of the southern hemisphere this species is also known from the Bartonian (Williams et al., 2004).

The lowermost part of the upper, non-calcareous interval contains species which appear frequently in the middle part of the lower interval, such as Chiropteridium eocaenicum. The re-occurrence of these rare specimens suggests that they are reworked. This, in turn, may be an indication of increased erosion of older deposits that took place during the initial stage of accumulation of the non-calcareous sands. This event seems to be associated with a possible hiatus marked by a $20 \mathrm{~cm}$ carbonate layer.

Wetzeliella simplex, that occurs at depths from 14.2 to 15.9 m only (Fig. 6), is known from Middle Eocene strata. It was described by Bujak (1980) from the Upper Barton Beds, which are correlated with the upper part of the NP17 Zone (Aubry, 1986). The same range was reported by Bujak et al. (1980) while Bujak (1979) restricted the total range of this species to the upper Middle and Upper Barton Beds correlated with the NP17 Zone (Aubry, 1986). The presence of $W$. simplex at the depth 14.2-15.9 m suggests that this interval can be correlated with the Upper Bartonian and the NP17 Zone. As a consequence, the lower part of the non-calcareous succession of the Leliszka borehole, at least to the depth of $14.2 \mathrm{~m}$, and a supposed hiatus (between the calcareous and non-calcareous intervals) are also Bartonian in age.

Samples from the higher interval of the non-calcareous succession (11.2-13.4 m) contain no Wetzeliella simplex. But their assemblages are generally similar to the ones from the lower samples, so their Late Bartonian age can be accepted. Impoverished assemblages (very rare specimens, dominated by Deflandrea) from samples from the overlying interval (8.8-10.5 m) cannot be used for dating; this interval may represent either the Upper Bartonian or the Lower Priabonian. A clue to its age may be the occurrence of Dracodinium rhomboideum in the interval 10.3-13.4 m (if not reworked - this is the second interval with this species: the first is in the basal part of the succession): the highest occurrence of this species in the Norwegian-Greenland Sea is correlated with the lower part of NP17 Zone (Eldrett et al., 2004). But earlier studies suggest a slightly older highest (top of the NP16) occurrence of this species (Coninck, 1986; Bujak and Mudge, 1994).

The age of the overlying topmost interval $(5.0-8.7 \mathrm{~m})$ is Lower Priabonian. This interpretation is based on the co-occurrence of Rhombodinium perforatum, a species of which the first appearance in earliest Priabonian is widely accepted (e.g., Williams and Bujak, 1985), and Areosphaeridium michoudii, which appeared for the last time in the North Sea Basin during the Early Priabonian (Bujak and Mudge, 1994). The latter event was correlated by Bujak and Mudge (1994; see also Bujak, 1994) with the top of the NP18 Zone. A younger, Upper Priabonian age of the youngest strata of the Leliszka borehole can be suggested if the data presented is correlated with the Carpathian ranges of both species. A. michoudii and $R$. perforatum were described by the author from Upper Eocene strata of the Magura Basin correlated with the NP19-20 Zone (Gedl, 2004; Gedl and Leszczyński, 2005). But the youngest assemblages from the Leliszka succession do not contain Reticulatosphaera actinocoronata, a characteristic species that appeared for the first time in Carpathian basins during the same zone (Gedl, 2004; Gedl and Leszczyński, 2005). Therefore, the Lower Priabonian age of the three topmost samples from the borehole studied can be correlated with the topmost part of the NP17 Zone and the NP18 Zone. This age is supported by the occurrence of Cordosphaeridium funiculatum (samples 15.7-15.9, 13.2-13.4 and 11.2-11.3 m) which, according to Williams et al. (2004), appeared for the last time during the Middle Priabonian, i.e., almost at the same time when $R$. actinocoronata appeared for the first time (e.g., Brinkhuis and Biffi, 1993).

\section{REWORKED DINOFLAGELLATE CYSTS}

Reworked Mesozoic dinoflagellate cysts in the material studied represent Jurassic and Cretaceous taxa (Appendix 2). 
Jurassic taxa are represented by Ctenidodinium combazii (Late Bajocian-Earliest Callovian; Riding and Thomas, 1992), Ctenidodinium continuum (latest Bajocian-earliest Oxfordian; Stover et al., 1996), presumably also Rhynchodiniopsis? sp. and Pareodinia sp.; they occur mainly in the lower, calcareous part of the succession. Their presence suggests erosion of Jurassic rocks (see e.g., Dayczak-Calikowska and Kopik, 1976; Dayczak-Calikowska and Moryc, 1988; Dayczak-Calikowska, 1997) during deposition of the Leliszka succession.

Cretaceous taxa have a broader distribution in the material studied; rare specimens occur also in the non-calcareous part. Cretaceous taxa such as Odontochitina operculata (Barremian-earliest Maastrichtian; Stover et al., 1996) and Palaeohystrichophora infusorioides (Late Albian-Early Maastrichtian; Williams et al., 2004), were eroded from Upper Cretaceous rocks that underlie the Paleogene and Neogene at Roztocze (see e.g., Hakenberg and Świdrowska, 2001). Some others such as Muderongia perforata (although described from the Turonian by Alberti, 1961, but presumably reworked there: see Davey and Verdier, 1974 and Monteil, 1991), Cribroperidinium sp. and, possibly, Pyxidiella? sp. may derive from Lower Cretaceous (Valanginian-Hauterivian strata) that also occur in the substratum (e.g., Świdrowska, 2007).

There are no Paleocene taxa in the material studied. The presence of reworked Early Eocene species is disputable - see Biostratigraphy section. Beside the species discussed, single specimens of Wetzeliella meckenfeldensis and Wilsonidinium echinosuturatum have been found. Their stratigraphical ranges are limited to the Ypresian and Lutetian respectively (Williams et al., 2004); this suggests that these specimens are reworked, although some authors report their occurrence in the Bartonian also (e.g., Heilmann-Clausen and Simaeys, 2005).

The distribution of reworked pre-Eocene taxa is shown in Appendix 2; they are highlighted by asterisks.

\section{PALAEOENVIRONMENT}

The calcareous, basal interval of the Leliszka borehole (18.3-38.7 m) contains rich and diverse dinoflagellate assemblages characteristic of a fully marine shelf environment (see e.g., Dale, 1996; Fig. 7). They consist of frequent chorate gonyaulacoids such as Spiniferites, Operculodinium, Dapsilidinium, Enneadocysta and Systematophora, proximate Cribroperidinium and Batiacasphaera, and peridinioids represented by Wetzeliella and Deflandrea. There are no significant qualitative changes, suggesting generally stable conditions throughout accumulation. The only exception is an acme of Lentinia serrata, which represents $40 \%$ of the assemblage in sample $25.5-25.7 \mathrm{~m}$. The assemblages studied contain almost no offshore species. Very rare specimens of Impagidinium and Ynezidinium brevisulcatum (for the palaeoenvironmental preferences of Impagidinium see e.g., Brinkhuis, 1994; Sluijs et al. 2005) have been found in samples from basal part (38.6-38.7, 35.5-35.7, 34.5-34.7 and 29.4-29.55 m). Their presence may indicate that the basal part of the succession studied was deposited in a relatively offshore marine environment compared to the higher interval, which lacks offshore species. However, it must be highlighted that Impagidinium (and morphologically similar Ynezidinium) occur in the material studied as very rare, single specimens per sample. Another characteristic feature of the assemblages from the calcareous interval is the rare occurrence of Homotryblium (mainly $\mathrm{H}$. pallidum), a genus widely associated with near-shore, lagoonal palaeoenvironments (e.g.,
Köthe, 1990; Sluijs et al., 2005; see also Dybkjær, 2004). Its proportion does not exceed $5 \%$, with only sample $35.5-35.7 \mathrm{~m}$ containing $20 \%$. The scarcity of Homotryblium may indicate a relatively offshore sedimentary setting; this view is supported by a relatively low percentage of terrestrial particles. However, the scarcity of Homotryblium may also result from specific conditions, including shore palaeorelief, not suitable for development of a lagoonal system inhabited by this genus. Common mechanical damage of dinoflagellate cysts in the material studied seem to be a result of relatively high-energy hydrodynamic conditions involved by, e.g., wave activity in the near-shore zone.

Some samples from the uppermost part of the calcareous interval (22.7-22.9, 20.7-20.9 and 18.3-18.5 m) show a unique palynofacies dominated by structureless particles; their presence indicates exceptional sedimentary conditions. Structureless organic matter is commonly associated with anoxic bottom environments (e.g., Batten, 1996). There are no indications of anoxic conditions in the case of the Leliszka succession, so the presence of structureless organic matter in the topmost part of the calcareous interval must reflect some other specific conditions. Possibly, it may be related to stagnant conditions caused by slowing of the sedimentation rate reflected by a $20 \mathrm{~cm}$ thick marly layer at the top of the calcareous interval.

The basal part of the higher, non-calcareous interval contains similar dinoflagellate cyst assemblages. This may indicate that the transition between calcareous and non-calcareous intervals occurred in similar palaeoenvironmental conditions. But the presence of some presumably reworked species, e.g., Chiropteridium eocaenicum, in the basal part of the non-calcareous interval, and a possible pause in sedimentation during deposition of the topmost part of the underlying strata, suggest that there is a hiatus between these two units, and that erosion of older strata took place during beginning of accumulation of the younger unit. Assemblages from the higher part of the non-calcareous interval show qualitative and quantitative impoverishment. In the calcareous interval they are dominated by chorate gonyaulacoids Spiniferites, Areosphaeridium michoudii, Operculodinium, Lingulodinium machaerophorum, Systematophora, proximate Batiacasphaera and peridinioid Deflandrea. But, many other species present in the lower interval become rare or absent, e.g., Enneadocysta, Hystrichokolpoma, Wetzeliella, Charlesdowniea, Dapsilidinium and Tectatodinium ?grande. Samples from the depths 14.2-14.3 and 12.5-12.65 m show slight enrichment of Homotryblium: 6.5 and $7.0 \%$, respectively. This may indicate shallowing of the basin, although in samples from 13.2-13.4 and 12.5-12.65 m single specimens of Ynezidinium brevisulcatum, an offshore species, have been found.

A more distinct change of palaeoenvironment is recorded in the samples from depths $10.3-10.5$ and $8.8-8.95$ m: quantitatively impoverished assemblages are dominated by Deflandrea specimens. Such an assemblage can be interpreted as indicative of a brackish palaeoenvironment since this genus is commonly believed to had been tolerant of low salinity waters (e.g., Köthe, 1990; Brinkhuis, 1994; Sluijs et al., 2005).

The higher part of the non-calcareous interval (samples from depths 8.5-8.7 and 7.1-7.25 m), distinguished by high proportion of aquatic algae and Homotryblium $(H$. pallidum and H. floripes: 12.6 and $13.5 \%$, respectively), was presumably deposited in a shallow, partly restricted marine basin.

The topmost sample from depth 5.0-5.2 m, like the ones from 8.8-10.5 m interval, yielded a highly taxonomically impoverished assemblage dominated by Deflandrea (almost 65\%) pointing to brackish conditions. 


\section{DISCUSSION}

\section{BIOSTRATIGRAPHY}

The age-interpretations of previous authors point generally to a Bartonian age for the lower (calcareous) part of the Sołokija succession, which agree with the interpretation given in this paper. Some inconsistences may result from various methods used and/or different intervals studied.

The Eocene succession of the Sołokija Graben was dated in two boreholes from the north-western part of the graben: Łaszczówka-29 and Piekiełko-30 (Fig. 1B) by Gaździcka (1994) who correlated the calcareous nannoplankton studied with the upper part of the Calcareous Nannoplankton Zone NP16, which, in turn, is correlated with the lower part of the Bartonian (Berggren et al., 1995). This conclusion was based on the presence of a few species that have known lowest occurrences in the upper part of this zone: Cribrocentrum faveolatum, Dictyococcites bisectus, Discoaster bifax. These species occur in the uppermost parts of the profiles studied by Gaździcka (1994): Cribrocentrum faveolatum (the lowest occurrence at the depth $10.2 \mathrm{~m}$ in P-30 borehole), Dictyococcites bisectus (occurrence in the 9.5-11 m interval in the $\measuredangle-29$ borehole), Discoaster bifax (with a lowest occurrence at the depth $11 \mathrm{~m}$ in the $Ł-29$ borehole), and only in the Piekiekko-30 borehole the latter species was found in the basal part (depth $50.5 \mathrm{~m}$ ). Gaździcka's results (upper part of the NP16 Zone) can be correlated with the Lower Bartonian age of the basal $2 \mathrm{~m}$ thick interval of the Solokija borehole (the upper part of the NP16 Zone is correlated with the Lower Bartonian; Berggren et al., 1995). But the higher part of the calcareous interval of the Sołokija succession is at least of Middle Bartonian age (as indicated by the occurrence of Lentinia serrata), which is younger than was suggested by Gaździcka (1994).

The interpretations of Buraczyński and Rzechowski (1998: p. 59) also point to the Bartonian age of the basal interval. They referred to the unpublished results of calcareous nannoplankton studies from sections at Łaszczówka, Piekiełko, Leliszka and Hrebenne by Gaździcka and Smagowicz, and correlated the lower (calcareous) part of the succession with the NP16 and NP17 zones (i.e., generally the same interpretation as proposed in this paper, but both zones embrace a wide interval of Upper Lutetian-Bartonian; Berggren et al., 1995) on the basis of the presence of Discoaster tani nodifer and Discoaster saipanensis, although both species are known also from the older NP16 Zone (Perch-Nielsen, 1985; Martini and Müller, 1986; see also Gaździcka, 1994: fig. 4) and no indications of NP17 Zone were noted by Gaździcka (1994). Foraminiferal assemblages with Truncorotaloides rohri described from the same material by Giel and Odrzywolska-Bieńkowa (in Buraczyński and Rzechowski, 1998) were correlated by these authors with the topmost part of the Middle Eocene (Buraczyński and Rzechowski, 1998) although T. rohri is known from a wider time-interval embracing the whole Middle Eocene. Pożaryska and Locker (1972) described T. cf. rohri from the Siemien Formation at Siemień; according to them this species is known in Poland from the Upper Bartonian-Lower Priabonian interval (see discussion in Uberna and Odrzywolska-Bieńkowa, 1977). Berggren et al. (1995) reported T. rohri from the Lutetian-Middle Bartonian (P10-P14 zones), whereas earlier authors reported the range of this species as limited to the upper part of the P9 to P14 zones correlated then with the topmost Ypresian-Bartonian (e.g., Toumarkine and Luterbacher, 1985).
Dinoflagellate cysts determined by Słodkowska (in Buraczyński and Rzechowski, 1998), including Areosphaeridium diktyoplokum, Lentinia serrata and Wetzeliella ovalis, suggest a Bartonian age for the lower (calcareous) part of the Sołokija succession. Precise comparison with Słodkowska's data is impossible since Buraczyński and Rzechowski (1998) neither referred to a full species list nor to precise sample location. They only mentioned a few species, among which the occurrence of Lentinia serrata and the acritarch Paucilobimorpha may be correlated with the high frequency of $L$. serrata and Paucilobimorpha in the material studied recorded in the upper part of the calcareous interval (depth 18.3-29.55 m). The presence of Lentinia serrata in the material of Słodkowska (in Buraczyński and Rzechowski, 1998) likely suggests that her material did not came from the basal interval (the lowermost Bartonian).

The upper, non-calcareous interval of the Sołokija succession contains no calcareous microfossils (Buraczyński and Rzechowski, 1998). Dinoflagellate cysts described by Słodkowska (in Buraczyński and Rzechowski, 1998) were interpreted as younger than Bartonian, but older than Rupelian, i.e., their age may be correlated with the Priabonian. This interpretation partly agrees with the one presented in this paper: the Priabonian age of the upper (non-calcareous) part of the Sołokija succession in Leliszka borehole is documented for the uppermost interval (above $8.7 \mathrm{~m}$ ) where Rhombodinium perforatum occurs. The basal part of the non-calcareous interval is Bartonian; its upper part can be correlated with the NP17 Zone.

Comparison of these all available data show the undoubted Bartonian age of the calcareous interval. A Bartonian age based on dinoflagellate cysts is consistent with foraminiferal, calcareous nannoplankton and previous palynological data. Radiometric datings of glauconite from boreholes obtained by Krzowski (1993) are also consistent, although less precise: $39.5 \pm 3.0 \mathrm{Ma}$ from the lowermost part of the Łaszczówka-29 succession, and $42.2 \pm 3.0 \mathrm{Ma}$ from the topmost layer of the Piekiełko-30, due to relatively high errors, can be either Late Lutetian, Bartonian and/or Early Priabonian - the Lutetian/Bartonian boundary is dated at $41.3 \mathrm{Ma}$, and the Bartonian/Priabonian boundary is dated at $37.0 \mathrm{Ma}$ in the standard chronostratigraphy scale of Berggren et al. (1995).

Another problem refers to a possible hiatus between the calcareous and non-calcareous intervals suggested in this study. None of the previous authors who had a chance of closer descriptions of the Sołokija Graben succession cores report such a possibility.

\section{CORRELATION WITH OTHER EOCENE SITES OF SE POLAND}

Epicontinental basin. The Eocene succession of the Sołokija Graben is commonly correlated with several other sites on the Lublin Upland and its vicinity, which are treated as coeval (e.g., Buraczyński and Rzechowski, 1998: p. 60). They lie to the north of the Lublin region, in area of Radzyń Podlaski-Siemień-Puławy. The best-known sites are in the vicinity of Siemien near Parczew. They were known already in the 19th century (Giedroyć, 1886), and were widely studied for microand macrofauna in the 1960s and 1970s (Woźny, 1966a, b, 1967, 1977; Uberna and Woźny, 1970; Pożaryska and Locker, 1972; Szczechura, 1977; Pożaryska, 1977); more recently Kosmowska-Ceranowicz et al. (1990) described also amber and calcareous nannoplankton there. The Paleogene succession at Siemien was included by Ciuk (1974) within the upper part of the Pomerania Beds, later distinguished as the Siemien 
Beds by Pożaryska (1977), now placed in the informal Siemień Formation (Piwocki, 2002). It is up to $5 \mathrm{~m}$ thick and rests on Upper Cretaceous marl and clay overlain by a thin Quaternary cover; it shows highly uneven development, being commonly reduced or missing, over distances of a few metres. According to Piwocki (2002), the Siemień Formation at Siemień consists of basal transgressive quartz gravel and calcareous quartz-glauconite sand with phosphorite concretions and frequent macrofaunal remains (thick-shelled bivalves, corals, bryozoans), which pass upwards to predominantly non-calcareous fine-grained sand and silt (see also Kasiński and Tołkanowicz, 1999). Pożaryska and Locker (1971) correlated foraminifera from the lower, calcareous, part of the Siemien Formation at Siemień with the Globigerapsis semiinvoluta Zone and calcareous nannoplankton with the NP16 Zone. Later, calcareous nannolankton from the same deposits were correlated by Pożaryska (1977) and Kosmowska-Ceranowicz and Pożaryska (1984) with the NP17 Zone, whereas Müller (in Kosmowska-Ceranowicz et al., 1990) correlated it with the NP18 Zone - basal Priabonian (Berggren et al., 1995). A similar, $3.15 \mathrm{~m}$ thick succession of the Siemien Formation was described by Mojski et al. (1966) from a borehole at Luszawa, some $15 \mathrm{~km}$ east of Siemień. No microfauna was studied, and they reported only macrofossils (corals and bivalves) highlighting their similarity to macrofauna from Siemień and suggested an Upper Eocene age for the Luszawa succession. To the north, the thickness of the Siemien Formation increases to 15-20 m at Antonin and Branica near Radzyń Podlaski (Uberna and Odrzywolska-Bieńkowa, 1977; Uberna, 1981). The Eocene at these sites is characterized by tripartite development: there are two intervals with quartz gravel, quartz-glauconitic sands and phosphorite concretion levels, the upper level containing frequent fossils; the third, topmost, interval consists of fine-grained quartz-glauconitic sands, calcareous in lower part, and non-calcareous in the upper part. Uberna and Odrzywolska-Bieńkowa (1977) correlated foraminifera assemblages from the basal interval with the Truncorotaloides rohri Zone that was considered as Lower Priabonian at that time. According to Piwocki (2002) the Siemien Formation at Siemien can be correlated with the middle and upper intervals of the Antonin and Branica sections. An Upper Eocene foraminifera assemblage (but different from the one with $T$. rohri) was described by Uberna and Odrzywolska-Bieńkowa (1977) from the basal part of an Eocene succession, over $40 \mathrm{~m}$ thick, from a borehole at Michów; this succession was included by Piwocki (2002) within the Siemien Formation.

Some other quartz-glauconitic successions from northern peripheries of the Lublin region (e.g., at Glinny Stok near Siemień, Łąkoć near Michów; Uberna, 1973; Fig. 8) were barren, and these were correlated with the Siemien Formation on the basis of lithological similarities (Uberna and Odrzywolska-Bieńkowa, 1977; Piwocki, 2002).

Precise age correlation of the Sołokija succession with the Siemien Formation is difficult due to lithofacies variability of the latter, and differing dates based on various fossil groups, the correlation of which has changed significantly during last few decades. The Sołokija succession shows a different lithological development: it is much thicker than the Siemien Formation in its stratotype, there are neither amber nor frequent macrofossils that are so characteristic of the Siemien Formation, nor were phosphorite concretions, so frequent in the Siemien Formation, observed. The results of most of biostratigraphical studies show an Upper Bartonian-Lower Priabonian age for the Siemień Formation. Pożaryska and Locker (1971) dated the basal part of the Siemien Formation to the G. semiinvoluta Zone (now the Porticulasphaera semiinvoluta Interval Zone) correlated by Berggren et al. (1995) with the Upper Bartonian-Lower Priabonian, and with the upper part of the NP17-lower part of the NP19-20 zones (Upper Bartonian-Lower Priabonian according to Berggren et al., 1995). This makes foraminiferal dating of Pożaryska and Locker (1971) partly coherent with interpretations of the calcareous nannoplankton studies of Pożaryska (1977) and Kosmowska-Ceranowicz and Pożaryska (1984) - NP17 Zone, and Müller (in Kosmowska-Ceranowicz et al., 1990) - NP18 Zone. The age suggested by Pożaryska and Locker (1971) on the basis of calcareous nannoplankton (NP16 Zone with Discoaster tani nodifer, i.e., Upper Lutetian-Lower Bartonian; Berggren et al., 1995) was criticized by Uberna and Odrzywolska-Bieńkowa (1977) who noted the lack of the index species in the Siemień assemblages of Pożaryska and Locker (1971). In such a case, the lower part of the Sołokija succession is older - Lower Bartonian (upper part of NP16 zone) than the lower part of the Siemien Formation at Siemien - Upper Bartonian ( $P$. semiinvoluta Zone). But it must be noted that Piwocki (2002) suggested that the oldest Eocene strata are absent at Siemień; they occur near Radzyń Podlaski, where Uberna and Odrzywolska-Bieńkowa (1977) included them to the T. rohri Zone (dated then as basal Priabonian) - now correlated (as the T. rohri-M. spinulosa Zone = P14 Zone) with the Middle Bartonian (i.e., lower part of the NP17 zone; Berggren et al., 1995). However, even then, this oldest part of the Siemien Formation near Radzyń Podlaski seems to be slightly younger than the lowermost part of the Sołokija succession.

Piwocki (2002) referred to unpublished results of Grabowska and Słodkowska who described dinoflagellate cysts from the Lublin region, including Siemień; Grabowska noted there the presence of Areosphaeridium diktyoplokum and Thalassiphora fenestrata interpreted as indicative of the Priabonian. However, Piwocki (2002) did not specify in which part of the Eocene succession these dinoflagellate cysts were found.

The above-mentioned sites include deposits of which an Eocene age is documented palaeontologically. There are several others on the Lublin Upland that show similar lithology (mainly glauconitic sands and silts) but their age is disputable Paleocene, Eocene, Oligocene or Middle Miocene, depending on the author. Krzowski (1993) studied glauconite from some of them and reported a radiometric age which ranges from Early-Middle Eocene through Late Eocene (e.g., Chełm vicinity, Żuków, Sporniak; see also Piwocki, 2004; Fig. 8). In cases such as Radawiec or Czułczyce, glauconite that gave an Eocene radiometric age was evidently reworked into Miocene deposits. No precise dating of the quartz-glauconite sands that occur east of Lubartów is yet available; the author's studies gave no results, the Lubartów sands containing no dinoflagellate cysts. Czuryłowicz et al. (2014) treated them as Upper Priabonian-Lower Rupelian but they gave no evidence for such an age-interpretation - these authors referred to the paper of Kasiński and Tołkanowicz (1999) and unpublished data of Kasiński et al. (1997) who correlated these deposits with the Upper Bartonian-Lower Priabonian Siemien Formation.

Outer Carpathians. A deep-water hemipelagic sedimentation prevailed in Carpathian basins during deposition of the Leliszka succession. Continuous successions of the Middleand Upper Bartonian and Lower Priabonian strata are represented mainly by a hemipelagic fine-grained facies known as the Variegated Shale (interlayering thin-bedded reddish and greenish claystones and siltstones; locally distinguished as the Green Shales when no reddish claystone is present) or distal turbiditic facies of the Hieroglyphic Beds (e.g., Ryłko, 2004); thick-bedded turbidites occur mainly in the southern part of the 


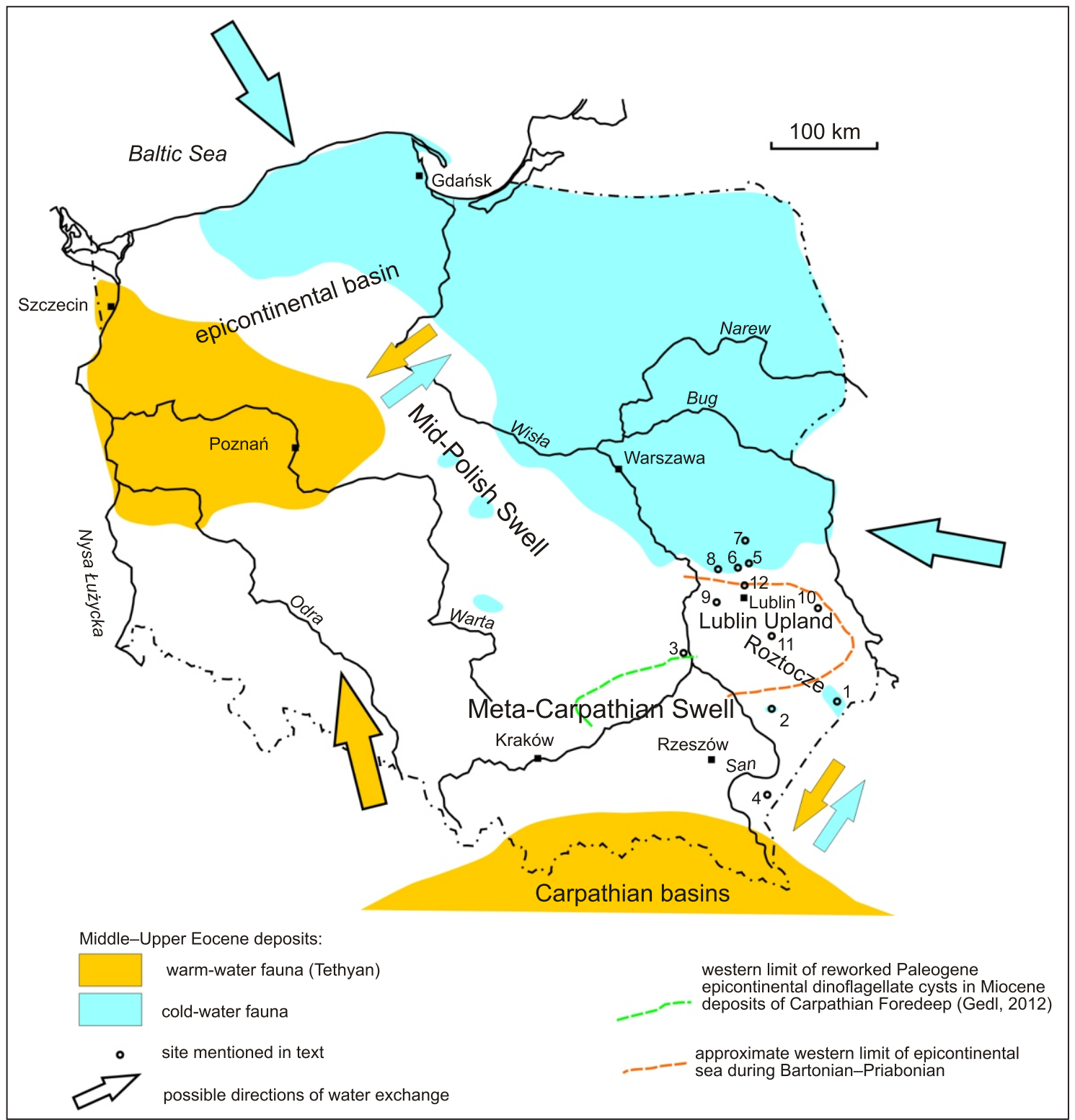

Fig. 8. Palaeogeography of SE Poland during the Bartonian-Priabonian

Extent of the sea is based on Grabowska and Słodkowska (1993), Słodkowska (2004), Myśliwiec and Śmist (2006) and compilation by Piwocki (2004); no distinction between Middle Eocene (mainly Bartonian) and Upper Eocene (Priabonian) is made due to inconsistences in precise correlation between particular lithological units to the geochronostratigraphic units that frequently changed during the past forty years; locations mentioned in text: 1 - Leliszka borehole, 2 - Łukowa-4 borehole, 3 - Zawichost, 4 - Koniusza, 5 - Siemień, 6 - Luszawa, 7 - Radzyń Podlaski, 8 Michów, 9 - Sporniak, 10 - Chełm, 11 - Żuków; 12 - Lubartów

Magura Basin (the Magura Formation; Birkenmajer and Oszczypko, 1989). A predominance of hemipelagic facies in the Outer Carpathian basins during the Bartonian and early Priabonian reflects the high sea level (e.g., Leszczyński and Uchman, 1991) characteristic of this time interval (see Haq et al., 1987).

The same facies pattern characterizes the Skole Basin, the northernmost Carpathian basin that borders with a land area that surrounds the Carpathian basins from the north - the Meta-Carpathian Swell (Fig. 8): the Bartonian-Lower Priabonian of the Skole Basin is represented by the Green Shales and the Hieroglyphic Beds (e.g., Rajchel, 1990). These deposits represent the basinal facies of the Skole Basin whereas the marginal ones are preserved in the form of subma- rine slump deposits known as the Popiele Beds. Dinoflagellate cyst analysis of the material from the Popiele Beds at Koniusza showed that the oldest assemblages occur in clasts of pale-coloured marl - they were dated as Early Bartonian (Gedl, 2013) being thus presumably coeval with the lowermost part of the Leliszka succession (sample from depth 38.6-38.7 m) - they contain no Lentinia serrata that appeared for the first time during the Middle Bartonian (Bujak et al., 1980; Williams et al., 2004) and occur in the higher part of the Leliszka succession (above depth $36.8 \mathrm{~m}$ ). Their taxonomic composition and palynofacies were interpreted as indicative of a marine shelf setting characterized by very low terrestrial influx; frequent hypersaline-indicative dinoflagellate cysts were interpreted as an evidence of lagoonal conditions in the hinterland (Gedl, 
2013). Younger, Priabonian assemblages found in the dark coloured mudstone that forms the bulk of the Popiele Beds can be partly correlated with the Priabonian part of the Leliszka succession (the youngest Late Priabonian assemblages with Reticulatosphaera actinocoronata from the Popiele beds are younger than the Early Priabonian of Leliszka; Gedl, 2013). Palaeoenvironmental interpretation of the Priabonian assemblages from the Popiele Beds suggested that they accumulated in a marine shelf environment which, in contrast to the older marly lithofacies, was situated in a zone of higher terrestrial influx, including presumably weak fluvial activity in the hinterland that, during the Early Bartonian, was absent (Gedl, 2013).

PALAEOPROVINCIAL AFFINITY OF DINOFLAGELLATE CYST ASSEMBLAGES AND THE PALAEOTECTONICS OF ROZTOCZE

Foraminiferal data show that the Late Eocene epicontinental sea in Poland was influenced by waters from two faunal provinces: Boreal and Tethyan (Mediterranean). Deposits in SE Poland (e.g., the Siemien Formation on the northern slopes of the Lublin Upland) contain boreal elements showing that this area was flooded by a transgression that came from the eastern regions (e.g., Pożaryska, 1977; Pożaryska and Odrzywolska-Bieńkowa, 1977). Tethyan elements found in NW Poland suggest that there was a connection between the epicontinental and Carpathian basins through the Moravian Gate (Piwocki, 2004). These two zones were presumably separated by the Mid-Polish Swell that during the Middle-Late Eocene formed a barrier (Pożaryska and OdrzywolskaBieńkowa, 1977; Jarosiński et al., 2009). However, precise reconstruction of its structure and the timing of its uplift is uncertain (see e.g., Krzywiec, 2006). Traces of faunal mixing between these two domains indicates that they were at least periodically connected with each other (Piwocki, 2004) but its precise reconstruction, especially in the SE Poland, is not possible due to almost complete removal of the Eocene deposits during the latest Eocene and/or post-Eocene uplift of the Mid-Polish Swell and the Meta-Carpathian Swell.

The dinoflagellate cysts from the Leliszka succession show similarities with those from the Boreal (North Sea) province. Almost all species found in the material studied are also known from localities in the U.K., Denmark, northern Germany and Belgium (e.g., Eaton, 1976; Bujak et al., 1980; Coninck, 1986, 1995; Bujak, 1994; Heilmann-Clausen and Simaeys, 2005; Köthe, 2007), but also from the Ukrainian and more eastern sites (Andreeva-Grigorovich et al., 2011; Vasilyeva, 2013; they also show similarities to the Bartonian Kisselovia ornata assemblage from northwestern Siberia; lakovleva et al., 2000). Many species from the material studied are believed to be typical high-latitude ones, e.g., Achomosphaera alcicornu, Lentinia serrata, Pentadinium laticinctum, Corrudinium incompositum, Achilleodinium biformoides (Brinkhuis and Biffi, 1993). These similarities of dinoflagellate cyst assemblages, and particularly the presence of North Sea species such as Wetzeliella simplex in the Lieliszki borehole, confirms that this part of the epicontinental basin in Poland was connected, especially during the Bartonian, with basin systems stretching from the North Sea to the Caspian Sea area (see Pożaryska, 1977: fig. 3). However, Pożaryska (1977) excluded a North Sea direction of the transgression that left Eocene deposits in the northern surroundings of the Lublin Upland; according to her it came from the east (see also Pożaryska and Odrzywolska-Bieńkowa, 1977). Odrzywolska-Bieńkowa and Pożaryska (1981), in turn, noted a boreal character of microfauna from Siemień. Pożaryska (1977) also excluded a direct connection of the epicontinental basin in SE Poland with the Carpathian basin; they may have been connected through the Moravia Gate in SW Poland (e.g., Pożaryska and Odrzywolska-Bieńkowa, 1977). But comparison of the Bartonian assemblages with approximately coeval ones from the marginal deposits of the Skole Basin ( Outer Carpathians) - the Popiele Beds exposed at Koniusza - show many common taxa as well (see Gedl, 2013). An undescribed species Gen. et spec. indet. C sensu Gedl 2013 that occurs in the basal part of the Leliszka succession is also known from the Lower Bartonian pale coloured clasts that occur in the Popiele Beds (Gedl, 2013). The same refers to species such as Corrudinium sp. A sensu Gedl (2013) or some Batiacasphaera species - their presence in both sites may indicate that a connection existed with the Carpathian basin. It must be also remembered that dinoflagellate cysts, as plankton, could much more easily migrate via surface water currents, whereas foraminifera known from the Eocene epicontinental sea, particularly benthic ones, were more bound by substrate and water depth. Shallow-marine areas on submerged heights between particular basins (as for example the Meta-Carpathian Swell) were no obstacle for dinoflagellate cysts, while they may have prevented foraminifera migrations.

Another clue pointing to the existence of at least temporary connections between epicontinental and Carpathian basins in SE Poland is the presence in the material studied of species believed to be typical Tethyan ones - e.g., Hemiplacophora semilunifera, Hystrichokolpoma globulus, Impagidinium maculatum, Ynezidinium brevisulcatum (see Brinkhuis and Biffi, 1993). Although their presence at Rozotocze confirms a seaway existence between these two basins during the Bartonian it does not unambiguously solve the problem of their location. The water exchange could have been conducted either through the Black Sea-Caspian Sea territories or directly through the Meta-Carpathian Swell in SW Poland. The latter hypothesis might be suggested by the presence in the material studied of Impagidinium specimens, which, although infrequent, suggests that the Roztocze Basin during the Bartonian was in connection with an open marine basin. This coincides with palynofacies and dinoflagellate cysts from the Early Bartonian clasts from the Popiele Beds from the southern side of the Meta-Carpathian Swell, which also show a lack of terrestrial influx (Gedl, 2013). Thus, the epicontinental basin of Roztocze and the Skole Basin were presumably separated during the Bartonian by the Meta-Carpathian Swell, but during a high-sea level phase it became partly submerged, forming and island arc allowing exchange between these two basins. On its southern slopes shallow-marine, lagoonal, environments occurred, inhabited by motile stages of the hypersaline genera Homotryblium and Polysphaeridium (Gedl, 2013).

This hypothesis opposes the conclusions of Pożaryska (1977) who compared the foraminifera from the Siemien Formation (northern slopes of the Lublin Upland) with the ones described by Wójcik (1904) and Syniewska (1937) from the Popiele Beds. Pożaryska (1977) found no similarities between assemblages from these two sites; she also compared other Eocene Carpathian assemblages and suggested that there was no direct connection between the Late Eocene Carpathian and the epicontinental marine basins in the Koniusza area. But it must be highlighted that the lower, fossiliferous part of the Siemien Formation is rather Bartonian, and Syniewska's and Wójcik's assemblages come from the fossiliferous matrix of the Popiele Beds that is Priabonian; dinoflagellate cysts on which an assumption of connection between Tethyan and epicontinental basins was based are Bartonian (Middle-Late Bartonian in the case of the Leliszka succession, and Early Bartonian in the case of marly clasts from the Popiele Beds). On 
the other hand, however, some species occurring in the material studied are absent from the Popiele Beds - this refers to, e.g., Chiropteridium eocaenicum, Wetzeliella eocenica and Charlesdowniea variabilis; their absence may reflect isolation of these two basins also in the Bartonian, but it may also reflect stratigraphical differences: no Middle-Late Bartonian assemblages have been described from the Popiele Beds so far (Gedl, 2013).

The precise reconstruction of the hypothetical seaways that connected Roztocze with Carpathian and epicontinental basins during the Bartonian high sea level phase (Fig. 8) is impossible due to the scarcity of preserved remnants of coeval deposits in SE Poland. Most likely the major connections went west of the present-day Lublin Upland, through the western Ukraine. Lack of reworked Eocene dinoflagellate cysts in Miocene deposits south-east of the Holy Cross Mts. (Gedl, 2012) suggests that this part of the Meta-Carpathian Swell was then land (see e.g., Karaszewski, 1966; Liszkowski and Stochlak, 1969; Felisiak, 1992). A disputable reconstruction encompasses the most of the Lublin Upland region where isolated patches of quartz-glauconitic deposits of uncertain age, devoid of fossils, occur (well-dated marine deposits occur on its northern slopes: see the section Correlation with other Eocene sites of SE Poland). Some of these were attributed to the Eocene on the basis of glauconite radiometric dates (Krzowski, 1993). The others, e.g., the sands east of Lubartów, are considered as Eocene-Oligocene though lack palaeontological evidence (e.g., Czuryłowicz et al., 2014). The lack of fossils suggests that these deposits accumulated in a very shallow, high-energy environment (Morawski, 1960; Czuryłowicz et al., 2014; note: Morawski refers to the Oligocene, then widely accepted, age of the sands at Lubartów) and/or in continental environments, such as the presumably residual deposits known as the Zawichost Sands. In both cases precise dating is barely possible and, hence, palaeogeographic reconstructions of the Lublin Upland region for this particular time interval is highly arbitrary. Nevertheless, the Lublin Upland was presumably already an uplifted structure in the Bartonian, surrounded to the north, east and south by marine basins.

The Early Priabonian dinoflagellate cysts from the Leliszka succession also show taxonomic similarities with Boreal and Tethyan floras. But composition of their assemblages, particularly their taxonomic impoverishment and frequent occurrence of near-shore Homotryblium and brackish Deflandrea, contrasts with that of coeval and slightly younger assemblages from marginal Carpathian deposits. Comparison of Priabonian dinoflagellate cysts from the Leliszki succession and the Priabonian part of the Popiele Beds at Koniusza (Gedl, 2013) show significant differences. The ones from Leliszki are characteristic of a restricted marine basin which became brackish, whereas assemblages from the Popiele Beds show high diversity typical of fully marine, offshore basins, as do ones from other, more southern localities within the Carpathian orogenic belt (see e.g., Couvering et al., 1981; Gedl, 1995, 1999, 2004, 2005a, b). Moreover, the palynofacies of the Priabonian deposits of the Popiele Beds suggest relatively high terrestrial influx from the north, i.e., from the Meta-Carpathian Swell that had to have been emergent during the Priabonian. This suggests isolation of the Roztocze Basin from the Carpathians by the Meta-Carpathian Swell, which presumably emerged during the earliest Priabonian and became a barrier separating the Carpathian and Roztocze basins. According to Pożaryska (1977: fig. 3) possible connections between these two basins during Priabonian were through the Moravian Gate (to the west) and through the Black Sea-Caspian Sea area.

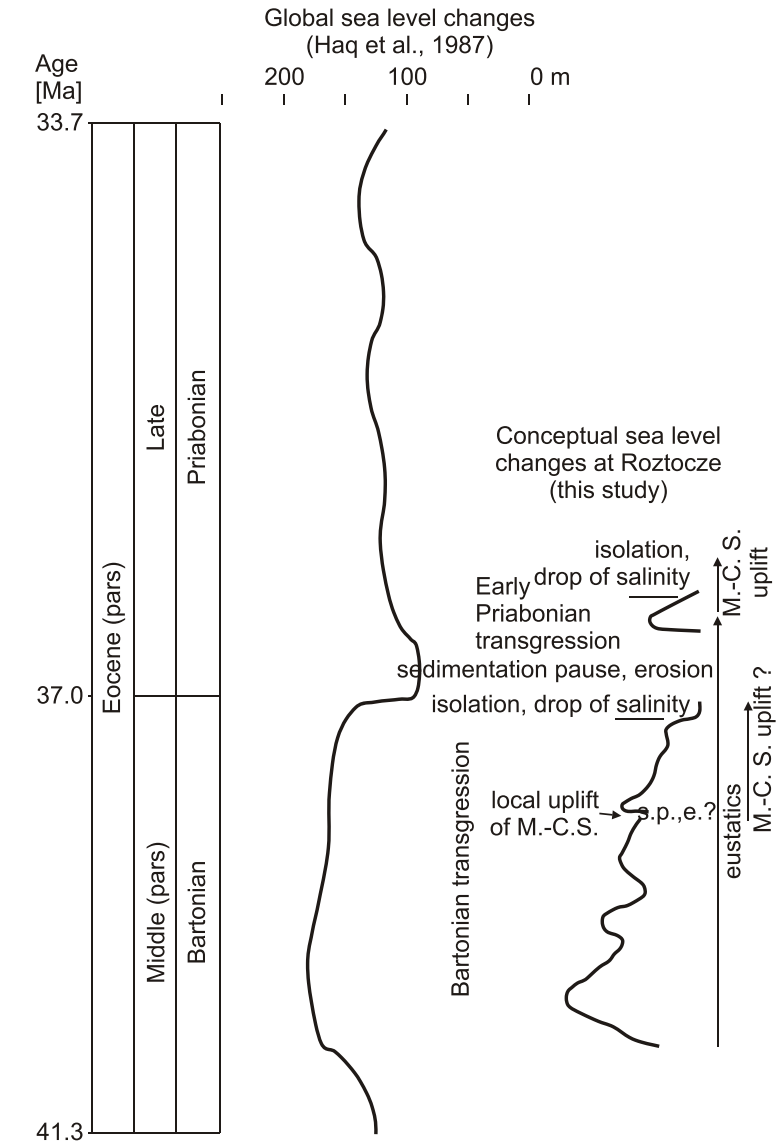

Fig. 9. Comparison of eustatic curve with a conceptual curve of sea level change in the Roztocze area during the Bartonian and Early Priabonian

Age after Berggren et al. (1995); M.-C.S. - Meta-Carpathian Swell; s.p.,e.? - sedimentation pause, erosion?

The presence of a marine basin at Roztocze (i.e., the southwestern flank of the Mid-Polish Swell and the northern surroundings of the Meta-Carpathian Swell) indicates that this region was not influenced by major uplif during the Bartonian, its appearance was rather caused by eustasy (Fig. 9). This was presumably also the reason for subsequent shallowing during the Late Bartonian, which might be associated with a global sea level fall close to the Bartonian/Priabonian turnover, rather (see Haq et al., 1987) than with the uplift of the swell. However, the latter option cannot be excluded: some small-scale uplift of the Meta-Carpathian Swell may have taken place: they may have been responsible for a sedimentary pause/slowdown recorded at the depth 18.3-18.5 m (Fig. 7). Further shallowing of the basin may have been caused by both eustasy and uplift of the Meta-Carpathian Swell; but the latter option seems to be less plausible since during the Early Priabonian a second transgression covered Roztocze, and the global sea level during the Early Priabonian was lower than during the Bartonian (Fig. 9), and so it could not have flooded elevated areas.

Shallowing of the Priabonian sea at Roztocze, in turn, was presumably caused by the Mid-Polish Swell uplift in its southeastern part since the Priabonian was a time of relatively small global sea level rise (see Haq et al., 1987; Fig. 9). 


\section{SUMMARY}

The biostratigraphical and palaeoenvironmental interpretation of dinoflagellate cyst assemblages described from the Leliszka borehole confirms the results of earlier studies suggesting the presence of a marine basin in the Roztocze area during the Bartonian-Early Priabonian. Its precise extent is unknown since its deposits are preserved only along the Sołokija Graben, which is a post-Eocene tectonic structure. Areas beyond the Sołokija Graben were eroded during the Oligocene and Miocene, and the only traces of Eocene transgression are reworked dinoflagellate cysts preserved in Miocene deposits of Roztocze and the Carpathian Foredeep Basin (Gedl, 2012).

The Eocene transgression started during the Early Bartonian; initially this was a relatively extensive (from the presence of rare Impagidinium specimens in basal part) although rather shallow basin characterized by high-energy bottom conditions. The latter feature is based on the presence of glauconite and frequently mechanically damaged dinoflagellate cyst specimens. There is no sign of large influx of land-derived material; this shows that during the early stages of the Bartonian basin at Roztocze there was no nearby large landmass with well-developed drainage systems.

The maximum of the Bartonian transgression is presumably recorded in the basal part of the Leliszka borehole at the depth of ca. 33-37 m where highly diverse assemblages occur associated with infrequent specimens of the offshore genus Impagidinium. Higher, a gradual shallowing of the basin is recorded that led to isolation of the basin and significant changes in water chemistry. It was caused presumably by eustatic lowering of sea level characteristic of the latest Batonian (Haq et al., 1987) although uplift of the Mid-Polish Swell and Meta-Carpathian Swell cannot be excluded. The latter were presumably responsible for sedimentation pause or slowdown reflected in a $20 \mathrm{~cm}$ thick layer enriched in carbonates and structureless organic matter at the depth of 18.3-18.5 m. Palaeoenvironmental conditions after this slowdown/pause, during the Middle-Late Bartonian (correlated with the NP17 Zone; depth 8.8-18.3 m), presumably due to basin shallowing, led to deposition of non-calcareous siliciclastic deposits. During their initial deposition, erosion of older strata took place; this is shown by the scattered occurrence of species that occur in the basal part of the underlying calcareous interval. The Bartonian basin of Roztocze was connected during its initial and late phases with the North Sea-Black Sea basin system (to the north-east); the present-day Lublin Upland region was presumably elevated in relation to Roztocze, and it formed a landmass or shallow-marine "platform" separating it to the north from the main epicontinental basin. It was also presumably connected with the Carpathian basins via the Meta-Carpathian Swell that during the high sea level phase of the Bartonian was presumably submerged. The final stage of the Bartonian basin at Roztocze (depth 8.8-10.5 m), involved further shallowing, isolation and the waters became brackish.

The topmost interval $(5.0-8.7 \mathrm{~m})$ represents strata deposited during the Early Priabonian transgression associated presumably with coeval global sea level rise (Haq et al., 1987). This short-lasting event left clastic deposits that had accumulated in an environment characterized by shallow-marine conditions (general impoverishment of taxonomical richness, frequent Homotryblium), that were possibly partly restricted (common algae). The Roztocze Basin during the initial stages of Early Priabonian transgression, was separated from the Carpathians by the emergent Meta-Carpathian Swell (to the south), and was connected with the epicontinental basin (to the north-east). It became quickly an isolated basin, presumably due to uplift of the Rozotocze area. As a consequence, its final stage, as in the case of the Bartonian basin, was characterized by brackish conditions (depth 5.0-5.2 m).

\section{SELECTED TAXONOMY}

\author{
Batiacasphaera hirsuta Stover, 1977 \\ (Fig. 5A-C)
}

Hair-like projections that cover the autophragm of this species show various distributions. Most specimens have a dense cover of isolated hairs (Fig. $5 \mathrm{~A}-\mathrm{C}$ ), but some have hairs that tend to fuse with each other (referred to commonly as Batiacasphaera sp.; Fig. 4M). This feature is easily visible under SEM. Some Batiacasphaera sp. specimens seem to possess very short hairs, barely visible under a light microscope (Fig. 5D-F).

Cordosphaeridium minimum (Morgenroth, 1966) Benedek, 1972 (Fig. 5G-O)

Specimens included in the present study to this species have an apical archaeopyle. This feature, noted earlier by Verteuil and Norris (1996), shows that this species should be transferred to another genus. The specimens observed also show various process morphologies that range from relatively short, massive, striate stems terminated with distinct platforms (Fig. $5 \mathrm{~J}-\mathrm{L}$ ), to much thinner smooth stems with little expansion at their ends (Fig. 5G-I), united proximally by high septa (Fig. 5M-O).

\section{Cannosphaeropsis? sp.} (Fig. 5S, T)

Rare specimens questionably attributed to this genus are characterized by a large pericoel (Fig. 5S) and processes that are united distally by thin trabeculae (Fig. 5S). The presence of a distinct pericoel make this species similar to Hystrichostrogylon, but the distal connections of the process are typical of Cannosphaeropsis.

Cleistosphaeridium cf. placacanthum (Deflandre et Cookson, 1955) Eaton, Fensome, Riding et Williams, 2001

(Fig. 5Z3, Z4)

A single specimen similar to $C$. placacanthum except for distally connected processes in the antapical area.

Cordosphaeridium cf. inodes (Klumpp, 1953) Eisenack, 1963 (Fig. 5Z2)

A species of Cordosphaeridium that closely resembles $C$. inodes; it differs, however, by very short processes. 
Diphyes cf. ficusoides Islam, 1983

(Fig. 5Z)

A species of Diphyes which seems to represent a transitional form between D. colligerum (Fig. 5Z1) and D. ficusoides. It resembles the latter by a slightly convex antapical process (Fig. 5Z), which, however, is thinner, not so "inflated", as in typical $D$. ficusoides.

\section{Dracodinium cf. rhomboideum (Alberti, 1961) Costa et Downie, 1979

$$
\text { (Fig. 5Z5) }
$$

A species of Dracodinium resembling $D$. rhomboideum in the rhomboidal outline of the pericyst. The periphragm of this species shows mosaic structure that differs from the usually smooth periphragm of $D$. rhomboideum.

\section{Ectosphaeropsis? sp}

(Fig. 5U)

This species resembles a species cf. Ectosphaeropsis burdigalenis described by Heilmann-Clausen and Simaeys (2005) from the basal Priabonian of the Danish Basin

\section{Elytrocysta? sp.}

(Fig. 5V, W)

This species, questionably assigned to Elytrocysta, has a spherical shape, an apical archaeopyle, and apparently a two-layered wall separated by densely-distributed short appendages. The outer, ectophragmal layer bears no parasutural features.

$$
\begin{gathered}
\text { Pyxidiella? sp. } \\
\text { (Fig. 5P-R) }
\end{gathered}
$$

Rare specimens attributed questionably to this genus have an elongate ellipsoidal shape with a cyst wall covered by densely distributed tiny granules. Archaeopyle type uncertain, presumably precingular formed by loss of a single paraplate. This interpretation of archaeopyle type is contradictory along with the taxonomic affinity of this species, since Pyxidiella have an intercalary archaeopyle; a precingular archaeopyle would suggest affinity with Pyxidinopsis. The dark colour of the specimens discussed suggests that they are reworked.

\section{Pyxidinopsis? sp.}

(Fig. 5X, Y)

Subsphaerical, slightly elongated species with a cyst wall composed of thin and homogenous endophragm and thick periphragm. Archaeopyle presumably precingular, formed by loss of a single paraplate.

Acknowledgements. I would like to thank T. Król (University of Maria Curie-Skłodowska, Lublin) for sample donation. T. Król and W. Jezierski (UMCS, Lublin) are acknowledged for discussions and aid during fieldwork related to the present study. M. Barski (Warsaw University) and O.N. Vasilyeva (Institute of Geology and Geochemistry, Ekaterinburg) are kindly acknowledged for critical reading of the manuscript and valuable comments that led to significant improvements.

\section{REFERENCES}

Agelopoulos, J., 1964. Hystrichostrogylon membraniphorum n.g n.sp. aus dem Heiligenhafener Kieselton (Eozän). Neues Jahrbuch für Geologie und Paläontologie Monatshefte, 11 673-675.

Agelopoulos, J., 1967. Hystrichosphären, Dinoflagellaten und Foraminiferen aus dem eozänen Kieselton von Heiligenhafen, Holstein. Dissertation des Grades eines Doktors der mathematisch-naturwissenschaftlichen Fakultät der EberhardKarls-Universität, Tübingen.

Alberti, G., 1961. Zur Kenntnis mesozoischer und alttertiärer Dinoflagellaten und Hystrichosphaerideen von Nord- und Mitteldeutschland sowie einigen anderen europäischen Gebieten. Palaeontographica, Abteilung A, 116: 1-58.

Andreyeva-Grigorovich, A.S., Zaporozhets, N.I., Shevchenko, T.V., Aleksandrova, H.N., Vasilyeva, O.N., Yakovleva, A.I., Stotland, A.B., Savitskaya, N.A., 2011. Atlas of Paleogene dinocysts of Ukraine, Russia and adjacent countries (in Russian). Naukova Dumka, Kiev.

Aubry, M.-P., 1986. Paleogene calcareous nannoplankton biostratigraphy of northwestern Europe. Palaeogeography, Palaeoclimatology, Palaeoecology, 55: 267-334.
Batten, D.J., 1996. Palynofacies and palaeoenvironmental interpretation. In: Palynology: Principles and Applications, 3 (eds. J. Jansonius and D.C. McGregor): 1011-1064. American Association of Stratigraphic Palynologists Foundation, Dallas, Texas.

Berggren, W.A., Kent, D.V., Swisher, C.C. III, Aubry, M.-P., 1995 A revised Cenozoic geochronology and chronostratigraphy. SEPM Special Publication, 54: 129-212.

Birkenmajer, K., Oszczypko, N., 1989. Cretaceous and Paleogene lithostratigraphic units of the Magura Nappe, Krynica Subunit, Carpathians. Annales Societatis Geologorum Poloniae, 59: 145-181.

Brinkhuis, H., 1994. Late Eocene to Early Oligocene dinoflagellate cysts from the Priabonian type-area (northeast Italy): biostratigraphy and palaeoenvironmental interpretation. Palaeogeography, Palaeoclimatology, Palaeoecology, 107 121-163.

Brinkhuis, H., Biffi, U., 1993. Dinoflagellate cyst stratigraphy of the Eocene/Oligocene transition in central Italy. Marine Micropaleontology, 22: 131-183.

Bujak, J.P., 1976. An evolutionary series of Late Eocene dinoflagellate cysts from southern England. Marine Micropaleontology, 1: 101-117. 
Bujak, J.P., 1979. Proposed phylogeny of the dinoflagellates Rhombodinium and Gochtodinium. Micropaleontology, 25 308-324.

Bujak, J.P., 1980. Dinoflagellate cysts and acritarchs from the Eocene Barton Beds of southern England. Special Papers in Palaeontology, 24: 36-91.

Bujak, J.P., 1994. New dinocyst taxa from the Eocene of the North Sea. Journal of Micropalaeontology, 13: 119-131.

Bujak, J.P., Mudge, D., 1994. A high-resolution North Sea Eocene dinocyst zonation. Journal of the Geological Society, 151: 449-462.

Bujak, J.P., Downie, C., Eaton, G.L., Williams, G.L., 1980. Dinoflagellate cyst zonation of the Eocene, southern England. Special Papers in Palaeontology, 24: 15-26.

Buraczyński, J., 1997. Roztocze: budowa - rzeźba - krajobraz (in Polish). Zakład Geografii Regionalnej UMCS, Lublin.

Buraczyński, J., Krzowski, Z., 1994. Middle Eocene in the Sołokija Graben on Roztocze Upland. Geological Quarterly, 38 (4): 739-753.

Buraczyński, J., Rzechowski, J., 1998. Eocen Roztocza (in Polish). In: LXIX Zjazd Naukowy Polskiego Towarzystwa Geologicznego, Sesja referatowa i konferencje terenowe: Budowa geologiczna Roztocza (100-lecie badań polskich geologów) (eds. Z. Krzowski, M. Harasimiuk, T. Brzezińska-Wójcik, Z. Michalczyk, J. Rzechowski and J. Superson): 51-63. Wydawnictwo Uniwersytetu Marii Curie-Skłodowskiej, Lublin.

Buraczyński, J., Brzezińska-Wójcik, T., Superson, J., 1992. Objaśnienia do Szczegółowej mapy geologicznej Polski 1:50 000, ark. Tomaszów Lubelski (in Polish). Państwowy Instytut Geologiczny, Warszawa.

Caro, Y., 1973. Contribution à la connaissance des dinoflagellés du Paléocène-Eocène inférieur des Pyrenées espagnoles. Revista Española de Micropaleontología, 5: 329-372.

Cieśliński, S., Rzechowski, J., 1993. Mapa geologiczna podłoża czwartorzędu Roztocza między Tomaszowem Lubelskim a Hrebennem (in Polish). In: Tektonika Roztocza i jej aspekty sedymentologiczne, hydrogeologiczne i geomorfologicznokrajobrazowe (eds. M. Harasimiuk, J. Krawczuk and J. Rzechowski): 38-46. Materiały polsko-ukraińskiej konferencji terenowej, Lublin-Lwów, 16-20 czerwca 1993, Lublin.

Cieśliński, S., Kubica, B., Rzechowski, J., 1994. Mapa geologiczna Polski, 1:200,000, ark. Tomaszów Lubelski, Dołhobyczów, B - mapa bez utworów czwartorzędowych (in Polish). Państwowy Instytut Geologiczny, Warszawa.

Ciuk, E., 1974. Lithostratigraphic schemes of the Palaeogene in Poland except for the Carpathians and the Carpathian Foredeep (in Polish with English summary). Biuletyn Instytutu Geologicznego, 281: 7-48.

Coninck, J., de, 1986. Organic walled phytoplankton from the Bartonian and Eo-Oligocene transitional deposits of the Woensdrecht borehole, southern Netherlands. Mededelingen Rijks Geologische Dienst, 40: 1-49.

Coninck, J., de, 1995. Microfossiles à paroi organique du Bartonien, Priabonien et Rupélien inférieur dans le sondage de Kallo; espèces significantives dans les sondages de Woensdrecht, Kallo et Mol. Mededelingen Rijks Geologische Dienst, 53: 65-105.

Couvering, J.A., van, Aubry, M.-P., Berggren, W.A., Bujak, J.P., Naeser, C.W., Wieser, T., 1981. The terminal Eocene event and the Polish connections. Palaeogeography, Palaeoclimatology, Palaeoecology, 36: 321-362.

Czuryłowicz, K., Lejzerowicz, A., Kowalczyk, S., Wysocka, A., 2014. The origin and depositional architecture of Paleogene quartz-glauconite sands in the Lubartów area, eastern Poland. Geological Quarterly, 58 (1): 125-144.

Dale, B., 1996. Dinoflagellate cyst ecology: modeling and geological applications. In: Palynology: Principles and Applications, 3 (eds. J. Jansonius and D.C. McGregor): 1249-1275. American Association of Stratigraphic Palynologists Foundation, Dallas, Texas.
Davey, R.J., Verdier, J.-P., 1974. Dinoflagellate cysts from the Aptian type sections at Gargas and La Bédoule, France. Palaeontology, 17: 623-653.

Dayczak-Calikowska, K., 1997. Jura środkowa (in Polish). Sedymentacja, paleogeografia i paleotektonika. Prace Państwowego Instytutu Geologicznego, 153: 269-282.

Dayczak-Calikowska, K., Kopik, J., 1976. Middle Jurassic. In: Geology of Poland, 1: Stratigraphy, part 2: Mesozoic (eds. S. Sokołowski, S. Cieśliński and J. Czermiński): 241-334. Wyd. Geol., Warszawa.

Dayczak-Calikowska, K., Moryc, W., 1988. Evolution of sedimentary basin and palaeotectonics of the Middle Jurassic in Poland (in Polish with English summary). Kwartalnik Geologiczny, 32 (1): 117-136.

Dybkjær, K., 2004. Morphological and abundance variations in Homotryblium-cyst assemblages related to depositional environments; uppermost Oligocene-Lower Miocene, Jylland, Denmark. Palaeogeography, Palaeoclimatology, Palaeoecology, 206: 41-58.

Eaton, G.L., 1976. Dinoflagellate cysts from the Bracklesham Beds (Eocene) of the Isle of Wight, southern England. British Museum (Natural History) Geology, Bulletin, 26: 227-332.

Eldrett, J.S., Harding, I.C., Firth, J.V., Roberts, A.P., 2004. Magnetostratigraphic calibration of Eocene-Oligocene dinoflagellate cyst biostratigraphy from the Norwegian-Greenland Sea. Marine Geology, 204: 91-127.

Felisiak, I., 1992. Oligocene-Early Miocene karst deposits and their importance for recognition of the development of tectonics and relief in the Carpathian Foreland, Kraków region, southern Poland (in Polish with English summary). Annales Societatis Geologorum Poloniae, 62: 173-207.

Gaździcka, E., 1994. Middle Eocene calcareous nannofossils from the Roztocze region (SE Poland) - their biostratigraphic and palaeogeographic significance. Geological Quarterly, 38 (4): 727-734.

Gedl, P., 1995. Middle Eocene dinoflagellate cysts from the Rogoźnik section, Flysch Carpathians. Acta Palaeobotanica, 35: 195-231.

Gedl, P., 1999. Palynology of the Eocene-Oligocene boundary in the Polish Flysch Carpathians - preliminary results (in Polish with English summary). Przegląd Geologiczny, 47: 394-400.

Gedl, P., 2000. Newly found marine Oligocene deposits in the Carpathian Foreland and its palaeogeographic consequences. Slovak Geological Magazine, 6: 155-157.

Gedl, P., 2004. Dinoflagellate cyst record of the Eocene-Oligocene boundary succession in flysch deposits at Leluchów, Carpathian Mountains, Poland. Geological Society Special Publications, 230: 309-324.

Gedl, P., 2005a. Late Eocene-early Oligocene organic-walled dinoflagellate cysts from Folusz, Magura Nappe, Polish Carpathians. Acta Palaeobotanica, 45: 27-83.

Gedl, P., 2005b. Stop 5 - Znamirowice: microfossil record of palaeogeographic changes in Carpathian basins during Late Eocene and Oligocene. In: Excursion Guide (ed. P. Gedl): 79-82. 5th Micropalaeontological Workshop, Szymbark, Poland.

Gedl, P., 2012. Reworked Eocene-Oligocene dinoflagellate cysts in the Miocene of the Carpathian Foredeep Basin: implications for Paleogene palaeogeography in SE Poland. Geological Quarterly, 56 (4): 853-868.

Gedl, P., 2013. Eocene dinoflagellate cysts from the Popiele beds at Koniusza (Skole Nappe, Flysch Carpathians, Poland): taxonomy, biostratigraphy, and palaeoenvironmental reconstruction of a marginal marine basin. Studia Geologica Polonica, 136: $1-197$.

Gedl, P., Leszczyński, S., 2005. Palynology of the Eocene-Oligocene transition in the marginal zone of the Magura Nappe at Folusz (Western Carpathians, Poland). Geologica Carpathica, 56: 155-167.

Giedroyć, A., 1886. Sprawozdanie z poszukiwań geologicznych dokonanych w guberni grodzieńskiej i przyległych jej powiatach 
Królestwa Polskiego i Litwy w roku 1878 (in Polish). Pamietnik Fizjograficzny, 6: 3-16.

Grabowska, I., Słodkowska, B., 1993. Katalog profili osadów trzeciorzędowych opracowanych palinologicznie (in Polish). Państwowy Instytut Geologiczny, Warszawa.

Hakenberg, M., Świdrowska, J., 2001. Cretaceous basin evolution in the Lublin area along the Teisseyre-Tornquist Zone (SE Poland). Annales Societatis Geologorum Poloniae, 71: 1-20.

Haq, B.U., Hardenbol, J., Vail, P.R., 1987. Chronology of fluctuating sea levels since the Triassic (250 million years ago to present). Science, 235: 1156-1167.

Heilmann-Clausen, C., Simaeys, S., van, 2005. Dinoflagellate cysts from the Middle Eocene to ?lowermost Oligocene succession in the Kysing research borehole, central Danish Basin. Palynology, 29: 141-204.

lakovleva, A.I., Kulkova, I.A., Cavagnetto, C., 2000. Eocene microphytofossils (dinoflagellate cysts and continental palynomorphs) of Northwestern Siberia (Severnaya Sosva Basin). Newsletters on Stratigraphy, 38: 13-38.

Jarosiński, M., Poprawa, P., Ziegler, P.A., 2009. Cenozoic dynamic evolution of the Polish Platform. Geological Quarterly, $\mathbf{5 3}$ (1): 3-26.

Karaszewski, W., 1966. Traces of earlier marine Tertiary in the Iłżanka River basin (in Polish with English summary). Kwartalnik Geologiczny, 10 (1): 153-156.

Kasiński, J.R., Tołkanowicz, E., 1999. Amber in the northern Lublin Region - origin and occurrence. In: Investigations into amber, Proceedings of the International Interdysciplinary Symposium: Baltic amber and other fossil resins 997 Urbs Gyddanyzc-1997 Gdańsk, 2-6 September 1977, Gdańsk (eds. A. Kosmowska-Ceranowicz and H. Paner): 41-51. The Archeological Museum in Gdańsk, Gdańsk.

Kosmowska-Ceranowicz, B., Pożaryska, K., 1984. On new research of Tertiary sediments in Polish Lowlands. Bulletin de l'Académie Polonaise des Sciences, Série des sciences de la Terre, 31: 49-58.

Kosmowska-Ceranowicz, B., Kociszewska-Musiał, G., Musiał, T., Müller, C., 1990. The amber-bearing Tertiary sediments near Parczew (in Polish with English summary). Prace Muzeum Ziemi, 41: 21-35.

Köthe, A., 1990. Paleogene dinoflagellates from northwest Germany. Geologisches Jahrbuch, A, 118: 1-111.

Köthe, A., 2007. Cenozoic biostratigraphy from the German North Sea sector (G-11-1 borehole, dinoflagellate cysts, calcareous nannoplankton). Zeitschrift der Deutschen Gesellschaft für Geowissenschaften, 158: 287-327.

Köthe, A., Piesker, B., 2007. Stratigraphic distribution of Paleogene and Miocene dinocysts in Germany. Revue de Paléobiologie, 26: 1-39.

Krzowski, Z., 1993. Trzeciorzędowe osady glaukonitowe na Wyżynie Lubelskiej w świetle geochronologii izotopowe glaukonitu (in Polish). Prace Naukowe Politechniki Lubelskiej, 231: 1-171.

Krzywiec, P., 2006. Structural inversion of the Pomeranian and Kuiavian segments of the Mid-Polish Trough - lateral variations in timing and structural style. Geological Quarterly, 50 (1): 151-168.

Krzywiec, P., 2007. Tectonics of the Lublin area (SE Poland) - new views based on results of seismic data interpretation (in Polish with English summary). Biuletyn Państwowego Instytutu Geologicznego, 422: 1-18.

Kulczycka, J., 1975. Sprawozdanie z badań geologicznozwiadowczych za żwirami w rejonie Tomaszowa Lubelskiego (in Polish). Archiwum CAG no. 385359, Warszawa.

Kutek, J., 2001. The Polish-Mesozoic Rift Basin. Mémoires du Muséum national d'histoire naturelle, 186: 213-236.

Leszczyński, S., Uchman, A., 1991. To the orgin of variegated shales from flysch of the Polish Carpathians. Geologica Carpathica, 42: 279-289.
Liszkowski, J., Stochlak, J., 1969. Distribution and genesis of Tertiary glauconite deposits in the area of the north-eastern margin of the Świętokrzyskie Mts. (in Polish with English summary). Przegląd Geologiczny, 17: 80-83.

Martini, E., Müller, C., 1986. Current Tertiary and Quaternary calcareous nannoplankton stratigraphy and correlations. Newsletters on Stratigraphy, 16: 99-112.

Michoux, D., 1985. Palynostratigraphie de l'Éocène de Montforten-Chalosse (Landes, France). Revue de Micropaléontologie, 28: 138-153.

Mojski, J.E., Rzechowski, J., Woźny, E., 1966. Upper Eocene at Luszawa on Wieprz river near Lubartów (in Polish with English summary). Przegląd Geologiczny, 14: 513-517.

Monteil, E., 1991. Morphology and systematics of the ceratioid group: a new morphographic approach. Revision and emendation of the genus Muderongia Cookson and Eisenack 1958. Bulletin des Centres de Recherches Exploration-Production Elf-Aquitaine, 15: 461-505.

Morawski, J., 1960. Characteristic of sands of littoral zone of the Lower Oligocene sea in the Lublin region (in Polish with English summary). Przegląd Geologiczny, 8: 628-633.

Morgenroth, P., 1966. Mikrofossilien und Konkretionen des nordwesteuropäischen Untereozäns. Palaeontographica, B, 119: 1-53.

Musiał, T., 1987. Miocene of Roztocze (south-eastern Poland) (in Polish with English summary). Biuletyn Geologiczny, 31: 5-149.

Myśliwiec, M., Śmist, P., 2006. Eocene and Oligocene sediments of the Tarnogród area (NE part of the Polish Carpathian Foredeep) (in Polish with English summary). Przegląd Geologiczny, 54: 724-730.

Ney, R., Burzewski, W., Bachleda, T., Górski, W., Jakubczak, K., Słupczyński, K., 1974. Outline of paleogeography and evolution of lithology and facies of Miocene layers on the Carpathian Foredeep (in Polish with English summary). Prace Geologiczne, 82: 3-64.

Odrzywolska-Bieńkowa, E., Pożaryska, K., 1981. An outline of the Tertiary stratigraphy of the Polish Lowlands (based on foraminifers). Bulletin de l'Académie Polonaise des Sciences, Série des sciences de la Terre, 29: 19-27.

Perch-Nielsen, K., 1985. Cenozoic calcareous nannofossils. In: Plankton Stratigraphy (eds. J. Bolli, K. Saunders and K. PerchNielsen): 427-554. Cambridge University Press, Cambridge.

Piwocki, M., 2002. Stratigraphy of amber-bearing deposits of northern Lublin Region, eastern Poland (in Polish with English summary). Przegląd Geologiczny, 50: 871-874.

Piwocki, M., 2004. Paleogen. In: Budowa geologiczna Polski. Tom I: Stratygrafia. Część 3a: Kenozoik, paleogen, neogen (eds. T.M. Peryt and M. Piwocki): 22-71. Państwowy Instytut Geologiczny, Warszawa.

Pożaryska, K., 1977. Upper Eocene foraminifera of east Poland and their palaeogeographical meaning. Acta Palaeontologica Polonica, 22: 3-54.

Pożaryska, K., Locker, S., 1971. Les organismes planctoniques de l'Eocene supérieur de Siemień, Pologne orientale. Revue de Micropaléontologie, 14: 57-72.

Pożaryska, K., Odrzywolska-Bieńkowa, E., 1977. On the Upper Eocene in Poland (in Polish with English summary). Kwartalnik Geologiczny, 21 (1): 59-72.

Rajchel, J., 1990. Lithostratigraphy of the Upper Palaeocene and Eocene sediments from the Skole Unit (in Polish with English summary). Zeszyty Naukowe AGH, Geologia, 48: 1-112.

Riding, J.B., Thomas, J.E., 1992. Dinoflagellate cysts of the Jurassic System. In: A Stratigraphic Index of Dinoflagellate Cysts (ed. A.J. Powell): 7-97. Chapman and Hall, London.

Ryłko, W., 2004. Karpaty (in Polish). In: Budowa geologiczna Polski. Tom I: Stratygrafia. Część 3a: Kenozoik, paleogen, neogen (eds. T.M. Peryt and M. Piwocki): 271-338. Państwowy Instytut Geologiczny, Warszawa. 
Rzechowski, J., 1997. Trzeciorzęd i czwartorzęd wschodniej części Wyżyny Lubelskiej i Roztocza na Mapie geologicznej Polski 1 : 200000 (in Polish). Przegląd Geologiczny, 45: 1202-1208.

Rzechowski, J., Kubica, B., 1995. Mapa geologiczna Polski, 1:200,000, ark. Tomaszów Lubelski, Dołhobyczów, A - mapa utworów powierzchniowych (in Polish). Państwowy Instytut Geologiczny, Warszawa.

Sluijs, A., Pross, J., Brinkhuis, H., 2005. From greenhouse to icehouse; organic-walled dinoflagellate cysts as paleoenvironmental indicators in the Paleogene. Earth-Science Reviews, 68: 281-315.

Słodkowska, B., 2004. Tertiary palynological record of the Middle Vistula River valley (central Poland) (in Polish with English summary). Przegląd Geologiczny, 52: 84-86.

Stover, L.E., Brinkhuis, H., Damassa, S.P., Verteuil, L., de, Helby, R.J., Monteil, E., Partridge, A.D., Powell, A.J., Riding, J.B., Smelror, M., Williams, G.L., 1996. Mesozoic-Tertiary dinoflagellates, acritarchs and prasinophytes. In: Palynology: principles and applications, 2 (eds. J. Jansonius and D.C. McGregor): 641-750. American Association of Stratigraphic Palynologists Foundation, Dallas, Texas.

Syniewska, J., 1937. Sur la faune de Foraminifères du flysch paléogène de Koniusza prčs de Dobromil (in Polish with French summary). Annales de la Société Géologique de Pologne, 13: 1-20.

Szczechura, J., 1977. Ostracods from the Upper Eocene of east Poland. Acta Palaeontologica Polonica, 22: 55-92.

Świdrowska, J., 2007. Cretaceous in Lublin area - sedimentation and tectonic conditions (in Polish with English summary). Biuletyn Państwowego Instytutu Geologicznego, 422: 63-77.

Toumarkine, M., Luterbacher, H., 1985. Paleocene and Eocene planktic foraminifera. In: Plankton Stratigraphy (eds. J. Bolli, K. Saunders and K. Perch-Nielsen): 87-154. Cambridge University Press, Cambridge.

Uberna, J., 1973. Fosforytonośność osadów trzeciorzędowych północnej Lubelszczyzny (in Polish). Kwartalnik Geologiczny, 17 (4): 600-601.

Uberna, J.W., 1981. Upper Eocene phosphate-bearing deposits in northern and eastern Poland. Bulletin de l'Académie Polonaise des Sciences, Série des sciences de la Terre, 29: 81-90.

Uberna, J., Odrzywolska-Bieńkowa, E., 1977. New localities of the Upper Eocene in northern parts of the Lublin region (in Polish with English summary). Kwartalnik Geologiczny, 21 (1): 73-87.
Uberna, J., Woźny, E., 1970. Punkt 5 - Siemień (in Polish). In: Przewodnik XLII Zjazdu Polskiego Towarzystwa Geologicznego, 3-5 września 1970, Lublin: 123-126.

Vasilyeva, O.N., 2013. Paleogene dinocysts from the Eastern Caspian Depression (the Uspenskaya SP-1 Well, Kazakhstan). Litosphere, 2013-1: 102-127.

Verteuil, L., de, Norris, G., 1996. Miocene dinoflagellate stratigraphy and systematics of Maryland and Virginia. Micropaleontology, 42, Supplement: 1-172.

Williams, G.L., Bujak, J.P., 1985. Mesozoic and Cenozoic dinoflagellates. In: Plankton Stratigraphy (eds. J. Bolli, K. Saunders and K. Perch-Nielsen): 847-964. Cambridge University Press, Cambridge.

Williams, G.L., Stover, L.E., Kidson, E.J., 1993. Morphology and stratigraphic ranges of selected Mesozoic-Cenozoic dinoflagellate taxa in the northern hemisphere. Geological Survey of Canada Paper, 92-10: 1-137.

Williams, G.L., Brinkhuis, H., Pearce, M.A., Fensome, R.A., Weegink, J.W., 2004. Southern Ocean and global dinoflagellate cyst events compared: index events for the Late Cretaceous-Neogene. Proceedings of the Ocean Drilling Project, Scientific Results, 189: 1-98.

Woźny, E., 1966a. Fosforyty i bursztyny z Siemienia koło Parczewa (in Polish). Przegląd Geologiczny, 14: 277-278.

Woźny, E., 1966b. Eocene at Siemień near Parczew (in Polish with English summary). Kwartalnik Geologiczny, 10 (4): 843-850.

Woźny, E., 1967. Występowanie numulitów w bartonie z Siemienia koło Parczewa (in Polish). Przegląd Geologiczny, 15: 419-420.

Woźny, E., 1977. Pelecypods from the Upper Eocene of east Poland. Acta Palaeontologica Polonica, 22: 93-112.

Wójcik, K., 1904. Dolno oligoceńska fauna Kruhela Małego pod Przemyślem (Warstwy z Clavulina Szabói), Część I. Otwornice i mięczaki (in Polish). Rozprawy Wydziału MatematycznoPrzyrodniczego Akademii Umiejętności, Serya III, 3 (43B): 489-569.

Wysocka, A., 2002. Clastic Badenian deposits and sedimentary environments of the Roztocze Hills across the Polish-Ukrainian border. Acta Geologica Polonica, 52: 535-561.

Ziegler, P.A., 1988. Evolution of the Arctic-North Atlantic and Western Tethys. AAPG Memoir, 43: 1-198.

Żelichowski, A.M., 1974. Obszar Radomsko-Lubelski (in Polish). In: Budowa geologiczna Polski. Tom IV. Tektonika cz. 1 (ed. W. Pożaryski): 113-128. Wyd. Geol., Warszawa. 